\title{
Electron Transfer Reduction of the Diazirine Ring in Gas-Phase Peptide Ions. On the Peculiar Loss of [ $\left.\mathrm{NH}_{4} \mathrm{O}\right]$ from Photoleucine
}

\author{
Aleš Marek, ${ }^{1}$ Christopher J. Shaffer, ${ }^{1}$ Robert Pepin, ${ }^{1}$ Kristina Slováková, ${ }^{2}$ \\ Kenneth J. Laszlo, ${ }^{1}$ Matthew F. Bush, ${ }^{1}$ František Tureček ${ }^{1}$ \\ ${ }^{1}$ Department of Chemistry, Bagley Hall, University of Washington, Seattle, WA 98195-1700, USA \\ ${ }^{2}$ Regional Center of Advanced Technologies and Materials, Department of Analytical Chemistry, Faculty of Science, Palacky \\ University, 77146, Olomouc, Czech Republic
}

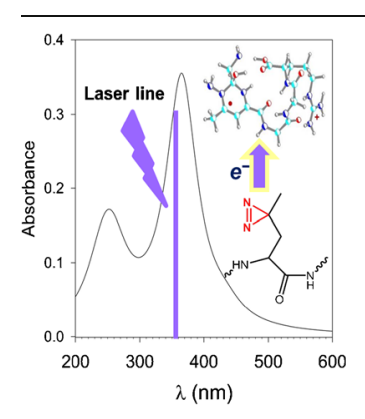

specifically involve the amide oxygen of the $N$-terminal residue. The structures, energies, and electronic states of the peptide radical species were elucidated by a combination of near-UV photodissociation experiments and electron structure calculations combining ab initio and density functional theory methods. Electron transfer reaching the ground electronic states of charge reduced $\left(\mathrm{GL}{ }^{*} \mathrm{GGR}+2 \mathrm{H}\right)^{+\bullet}$ cation-radicals was found to reduce the diazirine ring. In contrast, backbone $\mathrm{N}-\mathrm{C}^{\alpha}$ bond dissociations that represent a $60 \%-75 \%$ majority of all dissociations because of electron transfer are predicted to occur from excited electronic states.

Keywords: Electron transfer dissociation, Diazirine peptides, Excited states, Conformational analysis

Abstract. Electron transfer to gas-phase peptide ions with diazirine-containing amino acid residue photoleucine $\left(\mathrm{L}^{*}\right)$ triggers diazirine ring reduction followed by cascades of residue-specific radical reactions. Upon electron transfer, substantial fractions of $\left(\mathrm{GL}{ }^{*} \mathrm{GGR}+2 \mathrm{H}\right)^{+\bullet}$ cation-radicals undergo elimination of $\left[\mathrm{NH}^{4} \mathrm{O}\right]$ radicals and $\mathrm{N}^{2} \mathrm{H}^{2}$ molecules from the side chain. The side-chain dissociations are particularly prominent on collisional activation of long-lived $\left(G L^{*} G G R+2 H\right)^{+\bullet}$ cation-radicals formed by electron transfer dissociation of noncovalent peptide-18-crown-6-ether ion complexes. The ion dissociation products were characterized by multistage tandem mass spectrometry (MS ) and ion mobility measurements. The elimination of $\left[\mathrm{NH}^{4} \mathrm{O}\right]$ was elucidated with the help of ${ }^{2} \mathrm{H},{ }^{15} \mathrm{~N}$, and ${ }^{18} \mathrm{O}$-labeled peptide ions and found to Received: 18 August 2014/Revised: 22 October 2014/Accepted: 2 November 2014/Published Online: 17 December 2014

\section{Introduction}

$\mathrm{T}_{\mathrm{r}}^{\mathrm{b}} \mathrm{de}$ he diazirine ring offers a chromophore for the photolytic production of highly reactive carbene intermediates while demonstrating chemical stability compared with other common carbene precursors [1]. Aliphatic diazirines weakly absorb light at 350-370 $\mathrm{nm}$ and undergo competitive $\mathrm{N}_{2}$ elimination and rearrangement to diazoalkanes (Scheme 1) [2-4]. Diazirinecontaining tags, such as 3-trifluoromethyl-3-phenyldiazirine [5] have been used for carbene generation and, when synthetically incorporated into complex molecules, can be used to

Electronic supplementary material The online version of this article (doi:10.1007/s13361-014-1047-0) contains supplementary material, which is available to authorized users.

Correspondence to: František Tureček; e-mail: turecek@chem.washington.edu probe protein-ligand interactions by creating cross linkages [6-9]. An alternative approach to fully synthesizing each probe utilizes diazirine-tagged amino acids, such as L-2-amino-4,4azi-pentanoic acid (photoleucine, L*) or L-2-amino-5,5azihexanoic acid (photomethionine, $\mathrm{M}^{*}$ ) [10]. These residues can still be specifically incorporated into peptides by chemical synthesis, or used in protein expression to replace the natural Leu or Met residues [10].

Extending the solution studies into the gas phase, we have investigated the structures of peptide cations that were tagged with $\mathrm{L}^{*}$. In particular, $(\mathrm{GL} * \mathrm{GGK}+2 \mathrm{H})^{+},\left(\mathrm{GL} * \mathrm{GGK}-\mathrm{NH}_{2}+\right.$ $\mathrm{H})^{+}$, and their doubly charged analogues were found to adopt conformations in the gas phase that were quite similar to those of the corresponding peptide ions that contained the regular Leu residue [11]. These results were consistent with the fact that $\mathrm{L}^{*}$ is recognized as Leu surrogate in protein expression [10]. In addition, the similarity of $\mathrm{L}^{*}$ and Leu residues in 


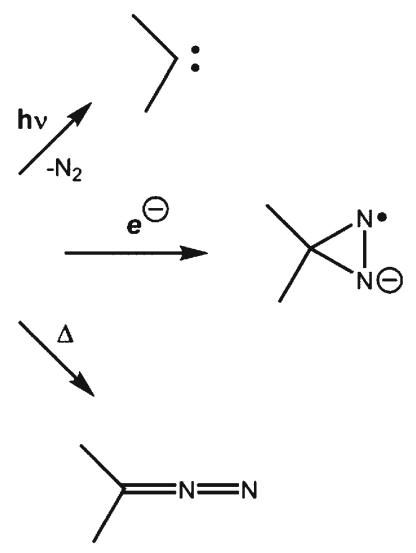

Scheme 1. Photochemical, electron transfer, and thermal reactions of diazirines

affecting gas-phase peptide ion 3D structures was promising for the use of $\mathrm{L}^{*}$ in conformational studies of gas-phase peptide ions through intramolecular covalent bond formation, which is analogous to reactions used in protein footprinting.

Whereas the photochemistry and photophysics of diazirines have been studied in detail, there is a dearth of data on the chemistry of diazirines following electron transfer. Mailer and coworkers reported an electron spin resonance study of 3phenyl-3-n-butyldiazirine and 3-trifluoromethyl-3phenyldiazirine where they detected transient anion-radicals upon electrochemical reduction in solution [12]. The susceptibility and fragility of diazirines to such reduction processes provides a reasonable explanation for why there are so few prior accounts of diazirines being studied by mass spectrometry where, until recently, electron impact was the favored ionization method. In our previous study of $\mathrm{L}^{*}$-containing peptide dications [13], we observed unusual dissociations upon electron transfer in the gas phase that resulted in elimination of a molecule of hydrazine that was accompanied by eliminations of $\mathrm{N}_{2} \mathrm{H}, \mathrm{N}_{2} \mathrm{H}_{3}, \mathrm{~N}_{2} \mathrm{H}_{5}$, and $\left[\mathrm{NH}_{4} \mathrm{O}\right]$ radicals. The branching ratios for these reactions depended on the peptide amino acid composition and sequence. The dissociations were interpreted as being triggered by electron attachment to the $\mathrm{L}^{*}$-diazirine ring, forming a transient anion-radical (Scheme 1) that underwent ring-cleavage dissociations accompanied by hydrogen transfers [13]. The intrinsic electron affinity of the diazirine moiety in GL*GGK-related neutral peptides was calculated as EA (adiabatic) $=1.34-1.53 \mathrm{eV}$, which was further augmented to $2.6 \mathrm{eV}$ by Coulomb effects of the singly charged lysine residue [13]. The most peculiar feature of these electroninduced diazirine dissociations was the elimination of $\left[\mathrm{NH}_{4} \mathrm{O}\right]$ radicals that do not represent stable species and must be composed of two molecules. Thermochemical arguments as well as deuterium labeling indicated that the elimination of $\left[\mathrm{NH}_{4} \mathrm{O}\right]$ most likely consists of a combined loss of an $\mathrm{NH}_{2}$ radical and water [13]. We now report a study of electron transfer dissociation of another diazirine-tagged peptide ion, $(\mathrm{GL} * \mathrm{GGR}+2 \mathrm{H})^{2+}$, with the aim of elucidating the radical chemistry of the diazirine ring in a peptide environment.
Experimental data from specific deuterium, ${ }^{15} \mathrm{~N}$, and ${ }^{18} \mathrm{O}$ labeling, product analysis by tandem mass spectrometry, ion mobility, and UV photodissociation [14] are brought to bear on elucidating the reaction mechanisms. The experimental methods are complemented by exhaustive conformational analysis of the peptide ions and electron structure theory calculations of structures, energies, and excited electronic states for intermediates and transition states.

\section{Experimental}

\section{Materials}

Photoleucine was purchased from Pierce Biotechnology (Rockford, IL, USA). All peptides were synthesized on Wang resin (Bachem Americas, Torrance, CA, USA) using the Fmoc technology according to literature procedures [15]. Fmoc Nprotected photoleucine and photomethionine were prepared according to the literature [16]. ${ }^{15} \mathrm{~N}$ - and $2,2-{ }^{2} \mathrm{H}_{2}$-glycine was purchased from Sigma-Aldrich (Milwaukee, WI, USA) and Fmoc-protected. ${ }^{18} \mathrm{O}$-Glycine was prepared by acid-catalyzed ${ }^{18} \mathrm{O} /{ }^{16} \mathrm{O}$ exchange in $90 \% \mathrm{H}_{2}{ }^{18} \mathrm{O}$ (Cambridge Isotope Laboratories, Tewksbury, MA, USA) and converted to an N-Fmoc derivative for solid-phase peptide synthesis.

\section{Methods}

Electron transfer dissociation (ETD) mass spectra were measured on a modified LTQ-XL ETD linear ion trap (LIT) mass spectrometer (ThermoElectron Fisher, San Jose, CA, USA) which was equipped with an auxiliary chemical ionization (CI) source for the production of fluoranthene anion-radicals. Peptide solutions $(5-10 \mu \mathrm{M})$ in 50/50/1 methanol/water/acetic acid were electrosprayed at $2.2-2.3 \mathrm{kV}$ from a pulled fused silica capillary into an open microspray ion source described previously [13]. Doubly charged ions were selected according to their $\mathrm{m} / \mathrm{z}$, stored in the LIT, and then allowed to react with fluoranthene anions injected into the LIT. The ion-ion reaction times were typically varied between 100 and $300 \mathrm{~ms} . \mathrm{MS}^{\mathrm{n}}$ experiments were carried out by isolating the fragment ions and exposing them to resonant collisional excitation or photoexcitation. Hydrogen/deuterium exchange of active protons was carried out as described in detail previously $[11,13]$ to achieve a high level (93\%) of deuterium incorporation. High-resolution ETD mass spectra were obtained on an LTQ-Orbitrap Velos instrument at a 60,000 resolving power. Ion mobility measurements were carried out on a modified Synapt G2 (Waters, Manchester, UK) instrument that was furnished with an ETD source and a special drift cell $[17,18]$. ETD on the Synapt G2 instrument was performed with azulene anion radical as electron donor. The drift cell He pressure was 1.5 Torr, the radiofrequency amplitude was 100 or $250 \mathrm{~V}$, which gave identical collision cross-sections. The data were processed to obtain absolute collision cross-sections as described previously [19]. 


\section{Photodissociation}

To accomplish photodissociation of trapped ions in the LIT, the LTQ-XL ETD mass spectrometer was modified as shown in Figure 1 (top panel) where the standard parts are labeled $\mathbf{a}-\boldsymbol{d}$ and the modified parts are labeled $\boldsymbol{e}-\boldsymbol{j}$. The CI source (e, Figure 1) was modified according to Ledvina et al. [20] by drilling a $0.039 "(1.0 \mathrm{~mm})$ diameter hole into the CI insert block to provide a line of sight path to the LIT. The backside vacuum gate to the CI source was replaced by an aluminum plate carrying a quartz window ( $\boldsymbol{f}$, ThorLabs, Newton, NJ, USA). The light beam was produced by an EKSPLA NL 301 HT (Altos Photonics, Bozeman, MT, USA) Nd-YAG laser (i) operating at $20 \mathrm{~Hz}$ frequency with a 3-6 ns pulse width. The laser is equipped with a third harmonics frequency generator producing a single $355 \mathrm{~nm}$ wavelength at $120 \mathrm{~mJ} /$ pulse peak power. The typical light intensity used in the photodissociation experiments was $15-20 \mathrm{~mJ} / \mathrm{pulse}$. The laser beam of a $6-\mathrm{mm}$ diameter is aligned by mirrors $(\boldsymbol{h})$ and focused by a telescopic lens (g) (all from ThorLabs) to pass the small aperture drilled in the CI source. The laser beam diameter in the LIT is estimated at 3-4 $\mathrm{mm}$ to ensure overlap with the trapped ions. Both the laser system and the LTQ-XL are set on an optical table $(j)$ for optimum alignment. The laser was interfaced to the LTQ by LabView software (National Instruments, Austin, TX, USA) that receives a signal from a TTL pulse on 14th pin of the J1 circuit board on the LTQ console. The timing of this TTL pulse can be controlled by the LTQ, and in this particular experiment it is selected to send a TTL pulse at the beginning of the desired UVPD step. The laser is operated in an internal triggering mode such that the lamp does not need to warm up for each desired pulse. Appropriately selected laser pulses are then triggered by LabView in response to the TTL pulse. The typical experimental time sequence of events is shown in Figure 1 (bottom panel). It consists of preparing by $\mathrm{MS}^{n} \mathrm{ETD} / \mathrm{CID}$ an ion with a chromophore absorbing at the laser wavelength and storing it in the LIT for a chosen time period. The mass-selected and stored ions are photodissociated with a chosen number of laser pulses. For example, 400-ms storage time can accommodate up to seven laser pulses spaced by $50 \mathrm{~ms}$. This allows one to vary the number of pulses and determine the photodissociation kinetics. Longer storage times of $>3 \mathrm{~s}$, allowing $>60$ laser pulses are readily realized. The photodissociation products can be further selected by mass and analyzed by CID or ETD.
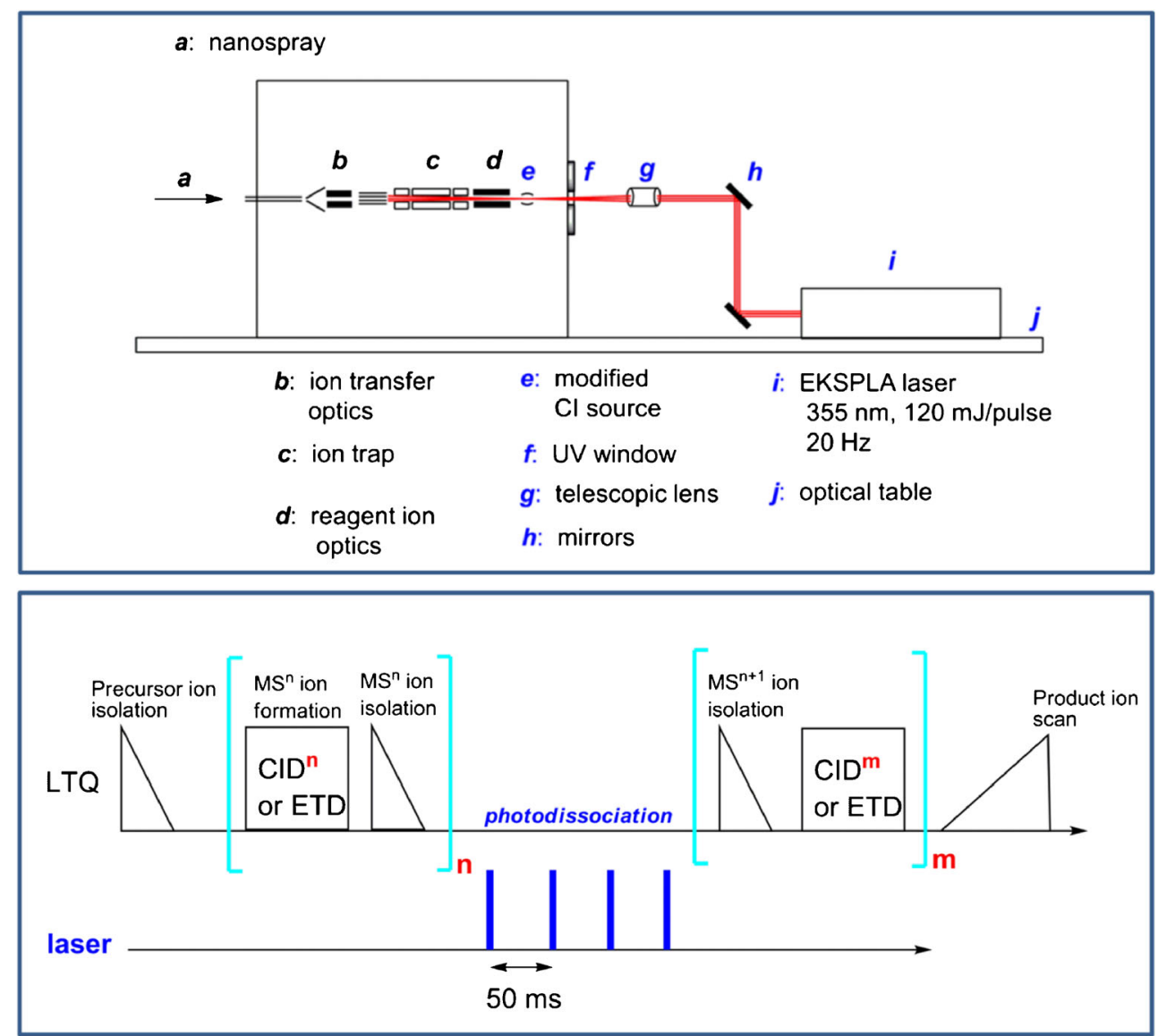

Figure 1. Top panel: Schematic (not to scale) of the UVPD experimental setup. The black-labeled letters denote the unmodified parts of the LTQ-XL mass spectrometer; the blue-labeled letters denote the new or modified parts. Bottom panel: Time sequence of ion chromophore preparation by ETD/CID-MS ${ }^{n}$ followed by ion isolation, $\mathrm{MS}^{\boldsymbol{n}+1}$ photodissociation, and MS ${ }^{n+1+m}$ analysis of massselected photodissociation products 


\section{Computations}

The search of lowest free energy conformers of (GL*GGR $+2 \mathrm{H})^{2+}$ followed a modified protocol [13]. First, a full conformational search was carried out using the ConformSearch engine [21, 22] for analogous (GLGGR $+2 \mathrm{H})^{2+}$ ions containing standard amino acid residues for which there are molecular dynamics parameters. The procedure consists of molecular dynamics mapping of the conformational space in a replica-exchange format [23] using the NAMD program [24] and the CHARMM force field [25]. The molecular dynamics trajectories were run with a step size of $1 \mathrm{fs}$ for $10 \mathrm{~ns}$ to generate and store 100,000 structures from each replica. Out of the 800,000 structures thus generated, 8000 were sampled at regular intervals and their geometries were fully optimized with PM6 [26]. The PM6 structures were sorted out into families according to their major hydrogen bonding patterns, and the lowest energy conformers from each family were ranked by energy. In the next step, single-point energies were calculated with B3LYP/6-31+G(d,p) [27, 28] for a subset of 125 lowest energy conformers from the PM6 list. These conformers were ranked according to the single-point B3LYP energies, duplicates were compacted, and a subset of 20 structures within a $30 \mathrm{~kJ} \mathrm{~mol}^{-1}$ energy range were fully optimized with B3LYP/6$31+\mathrm{G}(\mathrm{d}, \mathrm{p})$ and $\mathrm{M} 06-2 \mathrm{X} / 6-31+\mathrm{G}(\mathrm{d}, \mathrm{p})[29]$. Twelve lowest energy structures were characterized as local energy minima by harmonic frequency calculations that provided $298 \mathrm{~K}$ enthalpies and entropies. The calculated entropies included corrections for vibrational modes that were identified as hindered rotors [30, 31]. Final energy ranking was carried out on the basis of single point B3LYP, MP2, and M06-2X energy calculations with the 6$311++\mathrm{G}(2 \mathrm{~d}, \mathrm{p})$ basis set. The B3LYP and MP2 single point energy calculations used the B3LYP optimized structures. The optimized (GLGGR $+2 \mathrm{H})^{2+}$ structures are shown in Figure S1, Supplementary Material, the calculated relative energies are in Table S1, Supplementary Material. Next, we selected eight lowest energy (GLGGR $+2 \mathrm{H})^{2+}$ conformers and used PCModel (Serena Software, San Mateo, CA, USA) to rebuild the Leu side chain into that of $\mathrm{L}^{*}$ while retaining the peptide ion backbone folding pattern. In each of these new $\left(\mathrm{GL}^{*} \mathrm{GGR}+2 \mathrm{H}\right)^{2+}$ structures, the diazirine ring was oriented to form a hydrogen bond to one of the neighboring $\left(\mathrm{Gly}_{1}\right.$ or $\left.\mathrm{L}^{*}\right)$ amide $\mathrm{N}-\mathrm{H}$ bonds. Following full geometry optimization with B3LYP/6-31+G(d,p) and M06-2X/ $6-31+\mathrm{G}(\mathrm{d}, \mathrm{p})$ and frequency and single point energy calculations, we obtained a list of low $298 \mathrm{~K}$ free-energy structures for the $(\mathrm{GL} * \mathrm{GGR}+2 \mathrm{H})^{2+}$ ion, which are discussed in the Results section. Excited state energies and oscillator strengths were calculated using time-dependent DFT theory [32] with the M06-2X, LCBLYP [33], and $\omega \mathrm{B} 97 \mathrm{XD}[34,35]$ functionals and the 6$311++\mathrm{G}(2 \mathrm{~d}, \mathrm{p})$ basis set. All electron structure calculations were carried out with the Gaussian 09 suite of programs [36].

\section{Results}

\section{Cation-Radical Formation and Dissociations}

Electron transfer to $(\mathrm{GL} * \mathrm{GGR}+2 \mathrm{H})^{2+}$ ions resulted chiefly in two kinds of dissociations. One was standard backbone cleavages forming $C$-terminal sequence fragment ions of the $z$ and $\boldsymbol{y}$ type, which are assigned in the spectra (Figure 2a). The other type was side-chain dissociations affecting the $\mathrm{L}^{*}$ residue that amounted to $25 \%-42 \%$ of all radical-triggered fragmentations, representing the range of relative intensities for these fragment ions in ETD spectra of $(\mathrm{GL} * \mathrm{GGR}+2 \mathrm{H})^{2+}$ and its several ${ }^{2} \mathrm{H},{ }^{15} \mathrm{~N}$, and ${ }^{18} \mathrm{O}$ labeled isotopologues. Amongst the side-chain dissociations, ETD of $(\mathrm{GL} * \mathrm{GGR}+2 \mathrm{H})^{2+}$ resulted in a major loss of $\left[\mathrm{NH}_{4} \mathrm{O}\right]$, as established by accurate mass measurements $(\Delta m=34.0295 \mathrm{Da}$, theoretical $\Delta m=34.0293 \mathrm{Da}$ ). It is noteworthy that the ETD spectra showed no loss of $\mathrm{N}_{2}$, which is otherwise facile in collision-induced dissociation of diazirine-labeled peptide ions [11].

The eliminations of the $\mathrm{NH}_{4} \mathrm{O}$ radicals pointed to specific dissociations of charge-reduced cation-radicals, (GL*GGR $+2 \mathrm{H})^{+\bullet}$. These cation-radicals are present as stable $\mathrm{m} / \mathrm{z} 472$ ions in the Figure 2a ETD mass spectrum and can be isolated and further investigated by CID or UVPD. However, for further investigations, we used a more convenient technique for the specific generation of such stable, long-lived peptide cation radicals [13]. This technique consists of first generating by electrospray ionization a noncovalent peptide-18-crown-6ether complex [37-39] as a doubly charged gas-phase ion, which is then mass-selected $(m / z 368$, Figure $2 b)$, chargereduced, and stripped of the crown ether ligand by ETD or in combination with CID. Figure $2 b$ illustrates the specific formation of abundant, long-lived (GL*GGR $+2 \mathrm{H})^{+\bullet}(\mathrm{m} / z$ 472) ions upon ETD of the CE complex $(\mathrm{m} / z$ 368). This ion was selected by mass and investigated by collisional activation and photodissociation.

The CID-MS ${ }^{3}$ spectrum of the long-lived $\left(\mathrm{GL}^{*} \mathrm{GGR}+2 \mathrm{H}\right)^{+\bullet}$ ions (Figure 2c) was substantially different from the pertinent ETD spectrum in Figure 2a. In particular, CID of (GL*GGR $+2 \mathrm{H})^{+\bullet}$ showed dominant $m / z 438$ (ion $\boldsymbol{A}$, loss of $\left[\mathrm{NH}_{4} \mathrm{O}\right]$ ) and $m / z 442$ (ion $\boldsymbol{B}$, loss of $\mathrm{N}_{2} \mathrm{H}_{2}$ ) fragment ions, whereas amongst the sequence fragment ions only the $\boldsymbol{z}_{\mathbf{3}}(\mathrm{m} / \mathrm{z} 273)$ and $\boldsymbol{y}_{\mathbf{3}}(\mathrm{m} / \mathbf{z}$ 289 ) were formed competitively (Figure 2c). Note that the $z_{3}$ ion is accompanied by a metastable $\boldsymbol{x}_{\mathbf{3}}$ ion at $\mathrm{m} / \mathrm{z} 316$ [40-42], indicating that this radical-triggered backbone dissociation occurs in two steps [42].

The ETD and CID mass spectra of the $m / z 472$ (GL*GGR $+2 \mathrm{H})^{+\bullet}$ cation-radicals are compared in Figure S2 (Supplementary Material). The spectra showed similar relative branching ratios for the loss of $\left[\mathrm{NH}_{4} \mathrm{O}\right](\boldsymbol{A}, \mathrm{m} / \mathrm{z} 438)$ and the combined loss of $\mathrm{CH}_{2} \mathrm{NH}_{2}$, which was a major component, and $\mathrm{N}_{2} \mathrm{H}_{2}(\boldsymbol{B}$, $\mathrm{m} / \mathrm{z} 442$ ), which was a minor component. These neutral fragments were unambiguously identified by accurate mass measurements (30.0341 and $30.0220 \mathrm{Da}$ for $\mathrm{CH}_{2} \mathrm{NH}_{2}$ and $\mathrm{N}_{2} \mathrm{H}_{2}$, respectively). Loss of ${ }^{\bullet} \mathrm{CH}_{2} \mathrm{NH}_{2}$ was prominent upon ETD, whereas loss of $\mathrm{N}_{2} \mathrm{H}_{2}$ occurred on CID. Differences were observed for the loss of ammonia $(\mathrm{m} / \mathrm{z} 455)$, which was abundant in direct ETD of $(\mathrm{GL} * \mathrm{GGR}+2 \mathrm{H})^{2+}$, but was replaced by an $m / z 456$ ion due to loss of $\mathrm{NH}_{2}$ radical in the CID spectrum of $\left(\mathrm{GL}^{*} \mathrm{GGR}+2 \mathrm{H}\right)^{+\bullet}$ when prepared from the crown-ether complex. 
(a)

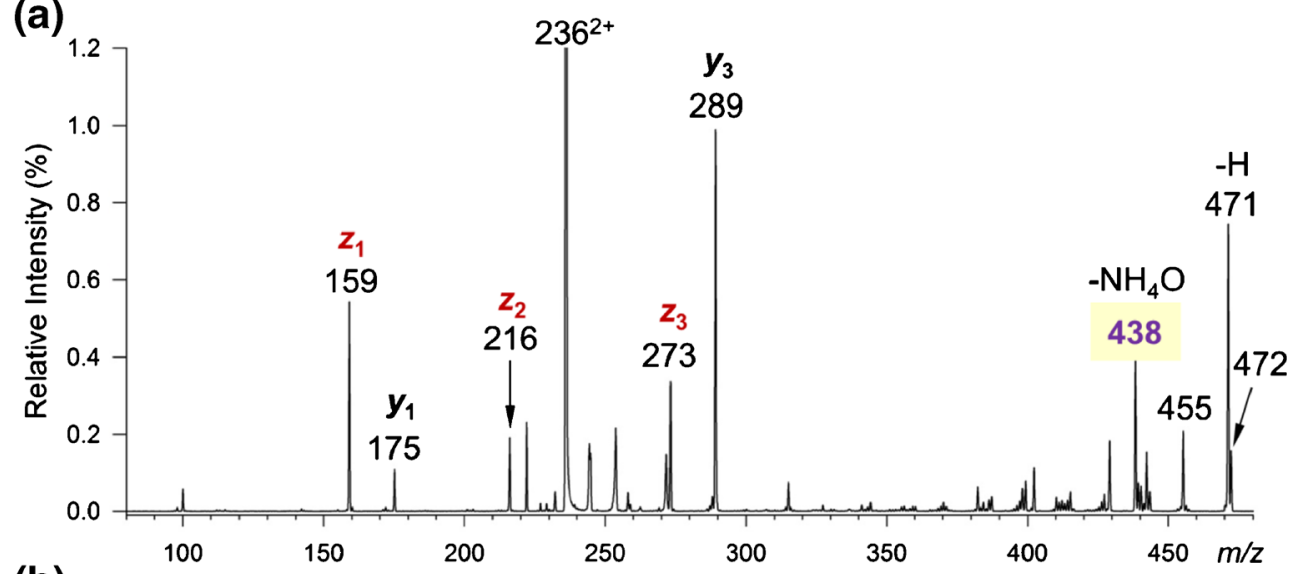

(b)


Figure 2. (a) ETD mass spectrum $(200 \mathrm{~ms})$ of $\left(\mathrm{GL}^{*} \mathrm{GGR}+2 \mathrm{H}\right)^{2+}$. (b) ETD mass spectrum $(200 \mathrm{~ms})$ of $\left(\mathrm{GL}{ }^{*} \mathrm{GGR}+\mathrm{CE}+2 \mathrm{H}\right)^{2+}$. Inset shows the peak of $\left(\mathrm{GL}^{*} \mathrm{GGR}+2 \mathrm{H}\right)^{+\bullet}$ at $\mathrm{m} / \mathrm{z} 472$. (c) $\mathrm{CID}$ spectrum of mass selected $\left(\mathrm{GL}{ }^{*} \mathrm{GGR}+2 \mathrm{H}\right)^{+\bullet}$ from the Figure $2 \mathrm{~b}$ spectrum. Insets show the enlarged regions of $\mathrm{m} / \mathrm{z} 435-475$ and $\mathrm{m} / \mathrm{z}$ 313-318

\section{Stable Isotope Labeling}

To elucidate the origin of the $\left[\mathrm{NH}_{4} \mathrm{O}\right]$ and $\mathrm{N}_{2} \mathrm{H}_{2}$ neutral species and the $\boldsymbol{A}$ and $\boldsymbol{B}$ ion structures we investigated the ETD and ETD-CID-MS ${ }^{3}$ spectra of $\left(\mathrm{GL}^{*} \mathrm{GGR}+2 \mathrm{H}\right)^{+\bullet}$ cation-radicals generated from isotopically labeled $\left(\mathrm{GL}^{*} \mathrm{GGR}+2 \mathrm{H}\right)^{2+}$ ions and their crown-ether complexes. The specific labeling concerned positions both proximate and remote from the $\mathrm{L}^{*}$ residue [e.g., $\left(\alpha, \alpha-{ }^{2} \mathrm{H}_{2}\right)-\mathrm{Gly}_{1},{ }^{15} \mathrm{~N}-\mathrm{Gly}_{1},{ }^{18} \mathrm{O}-\mathrm{Gly}_{1},\left(\alpha, \alpha-{ }^{2} \mathrm{H}_{2}\right)-\mathrm{Gly}_{3}-$ $\left(\alpha, \alpha-{ }^{2} \mathrm{H}_{2}\right)-\mathrm{Gly}_{4}$, and fully exchanged $\left({ }^{2} \mathrm{H}_{13}\right)$ ions]. The ETD spectra and their detailed analysis are presented in the Supplementary Material (Figures S3-S7). To summarize the results, the loss of $\left[\mathrm{NH}_{4} \mathrm{O}\right]$ was found to specifically involve the $\mathrm{N}$ terminal Gly amide oxygen but not the nitrogen of the $N$ terminal amino group. Both exchangeable and nonexchangeable hydrogen atoms were incorporated in the $\left[\mathrm{NH}_{4} \mathrm{O}\right]$ neutrals. However, the nonexchangeable $\mathrm{H}$ atoms did not originate from the $\mathrm{Gly}_{1}, \mathrm{Gly}_{3}$, and $\mathrm{Gly}_{4} \alpha$-positions. The loss of $\mathrm{N}_{2} \mathrm{H}_{2}$ was found to involve both exchangeable and 
nonexchangeable hydrogen atoms but not the nitrogen atom of the $N$-terminal amino group.

\section{Multistage CID and Photodissociation of A Ions}

To further characterize the loss of $\left[\mathrm{NH}_{4} \mathrm{O}\right]$, we obtained $\mathrm{MS}^{4}$ mass spectra of the $\boldsymbol{A}$ ions using CID. The CID-MS ${ }^{4}$ spectrum of $\boldsymbol{A}(\mathrm{m} / \mathrm{z} 438$, Figure 3a) showed dominant secondary fragment ions formed by consecutive losses of ammonia $(\mathrm{m} / z 421$, $404)$, water $(\mathrm{m} / \mathrm{z} 420)$, and several backbone fragments. Interestingly, most backbone fragment ions contained the $N$-terminus [e.g., $m / z 307, m / z 281\left(\boldsymbol{c}_{4}\right)$, and $m / z 264\left(\boldsymbol{b}_{4}\right)$ ]. These were unequivocally identified by the appropriate mass shifts in the spectra of ions generated from the ${ }^{15} \mathrm{~N}$ and deuterium labeled isotopomers, ${ }^{15} \mathrm{~N}-\mathbf{A}$ and ${ }^{2} \mathrm{H}_{2}-\mathbf{A}$, respectively (Figure $3 b, c$ ). The spectra indicated that the complementary $\boldsymbol{y}_{\mathbf{1}}(\mathrm{m} / \mathrm{z} 175)$ fragment competed for the proton with the $\boldsymbol{b}_{\mathbf{4}}$ ion. The fact that the $\boldsymbol{b}_{\mathbf{4}}$ and $\boldsymbol{c}_{\mathbf{4}}$ fragments, which did not contain basic amino acid residues, were able to compete for the proton with the Arg residue indicated that the $\mathrm{N}$-terminal moiety contained a highly basic functional group newly created by the loss of $\left[\mathrm{NH}_{4} \mathrm{O}\right]$. Conversely, the presence of the $\boldsymbol{y}_{\mathbf{1}}$ ion indicated that the Arg residue was not modified by the radical elimination. The CID$\mathrm{MS}^{4}$ spectrum also displayed $\boldsymbol{c}_{4}$ and minor $\left(z_{1}-\mathrm{H}\right)(\mathrm{m} / z$ 158) fragment ions. These indicated that the backbone dissociation leading to these fragment ions can be viewed as a charge-

(a)

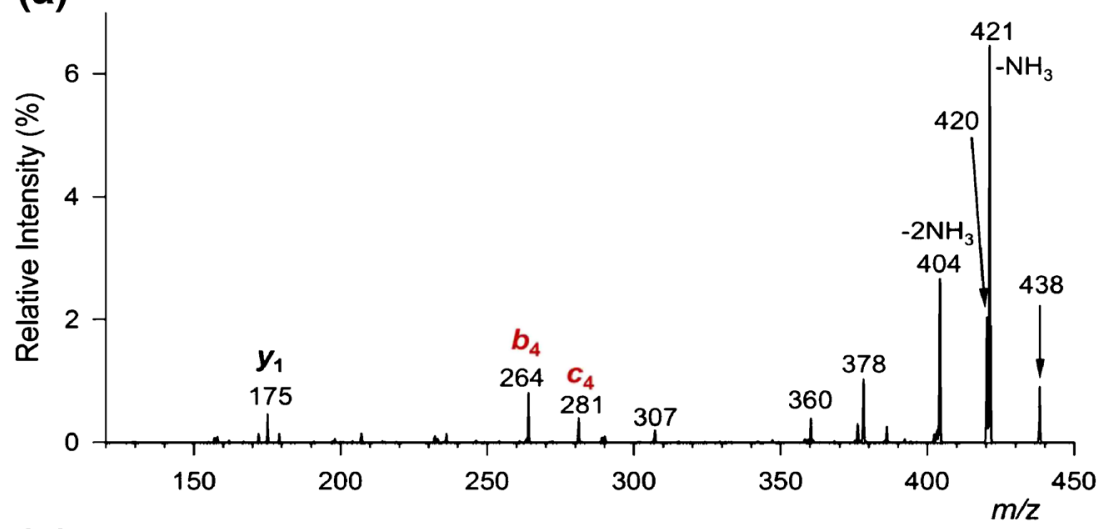

(b)

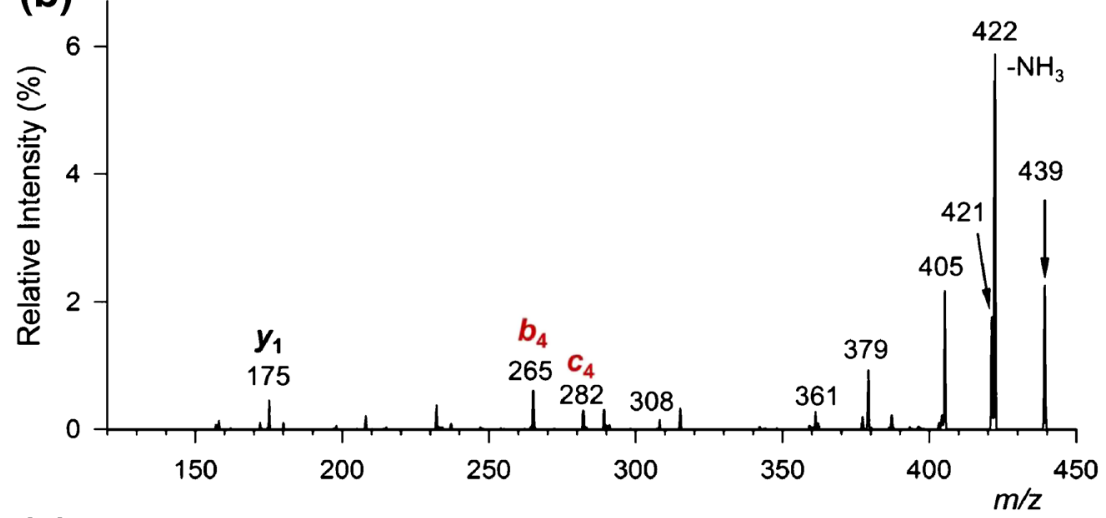

(c)



Figure 3. CID-MS ${ }^{4}$ mass spectra of (a) $m / z 438$ A ion from GL ${ }^{*}$ GGR, (b) $m / z 439$ A ion from ${ }^{15} \mathrm{~N}-\mathrm{GL}^{*} \mathrm{GGR}$, and (c) $m / z 440 \mathbf{A}$ ion from $\left({ }^{2} \mathrm{H}_{2}\right) \mathrm{GL}{ }^{*} \mathrm{GGR}$ 
remote elimination of the Arg residue analogous to a heteroretro-ene thermal alkene elimination from alkyl amides [43, 44]. The CID-MS ${ }^{4}$ spectrum of the $m / z 440{ }^{2} \mathrm{H}_{2}$-A ion from the $\left(\alpha, \alpha-{ }^{2} \mathrm{H}_{2}\right)-\mathrm{Gly}_{1}$ peptide (Figure $3 \mathrm{c}$ ) provided some clues as to the structure and backbone dissociations in these fragment ions. The spectrum shows a partial H/D exchange between the $y_{1}$ and $\boldsymbol{b}_{\mathbf{4}}$ ions, as evidenced by the $\mathrm{m} / \mathrm{z} 175 \rightarrow \mathrm{m} / \mathrm{z} 176$ and $\mathrm{m} / \mathrm{z} 266 \rightarrow$ $\mathrm{m} / \mathrm{z} 265$ mass shifts. This indicates that one of the formerly inactive $\left(\alpha, \alpha-{ }^{2} \mathrm{H}_{2}\right)-\mathrm{Gly}_{1}$ hydrogen atoms became exchangeable in the ${ }^{2} \mathrm{H}_{2}-\mathrm{A}$ ion.

Further results characterizing the $\boldsymbol{A}$ ions were obtained by UV photodissociation at $355 \mathrm{~nm}$ (UVPD). The $(\mathrm{GL} * \mathrm{GGR}+2 \mathrm{H})^{+} \bullet$ cation-radical $(\mathrm{m} / \mathrm{z} 472)$ and its ${ }^{15} \mathrm{~N}$-isotopologue $(\mathrm{m} / \mathrm{z} 473)$ were generated as long-lived ions by ETD of the corresponding crownether complexes, selected by mass, and exposed to nine laser pulses at $15 \mathrm{~mJ} /$ pulse. The UVPD spectra obtained under these conditions (Figures $4 \mathrm{a}$ ) showed that the $\left(\mathrm{GL}^{*} \mathrm{GGR}+2 \mathrm{H}\right)^{+}$ cation-radicals contained a chromophore group that absorbed at $355 \mathrm{~nm}$. UVPD of both $\left(\mathrm{GL}^{*} \mathrm{GGR}+2 \mathrm{H}\right)^{+\bullet}(\mathrm{m} / z$ 472) and its
${ }^{15} \mathrm{~N}$-isopologue $(\mathrm{m} / \mathrm{z} 473$, Figure $4 \mathrm{~b})$ showed a dominant loss of an $\mathrm{H}$-atom in addition to the loss of $\left[\mathrm{NH}_{4} \mathrm{O}\right]$, whereas the peaks due to losses of $\mathrm{NH}_{2}$ and $\mathrm{N}_{2} \mathrm{H}_{2}$ were absent (Figure 3). UVPD also produced minor peaks at $\mathrm{m} / z 444(\mathrm{~m} / z 445$ from the ${ }^{15} \mathrm{~N}$-labeled ion) because of the elimination of $\mathrm{CO}$ or $\mathrm{N}_{2}$. Note that the enhanced dissociation by loss of a H-atom upon UVPD was completely absent in the CID-MS ${ }^{3}$ spectra of these ions (Figures S2-S6, Supplementary Material). For comparison, we obtained CID-MS ${ }^{4}$ mass spectra with collisional excitation set at a low normalized collision energy $(\mathrm{NCE}=11)$ and long exposure $(500 \mathrm{~ms})$; these spectra were very similar to the more usual CID spectra obtained at higher NCE and $30 \mathrm{~ms}$ excitation time and showed no loss of $\mathrm{H}$ atoms. There was no dissociation when the $(\mathrm{GL} * \mathrm{GGR}+2 \mathrm{H})^{+\bullet}$ ions were stored for $500 \mathrm{~ms}$ in the LIT at $\mathrm{NCE}=0$ and in the absence of photoexcitation.

In contrast to the $(\mathrm{GL} * \mathrm{GGR}+2 \mathrm{H})^{+\bullet}$ cation-radicals, UVPD of the $\boldsymbol{A}$ ion $(\mathrm{m} / \mathrm{z} 438)$ induced no dissociation. We concluded that this even-electron ion did not have a chromophore group absorbing at $355 \mathrm{~nm}$. This provided additional evidence for the
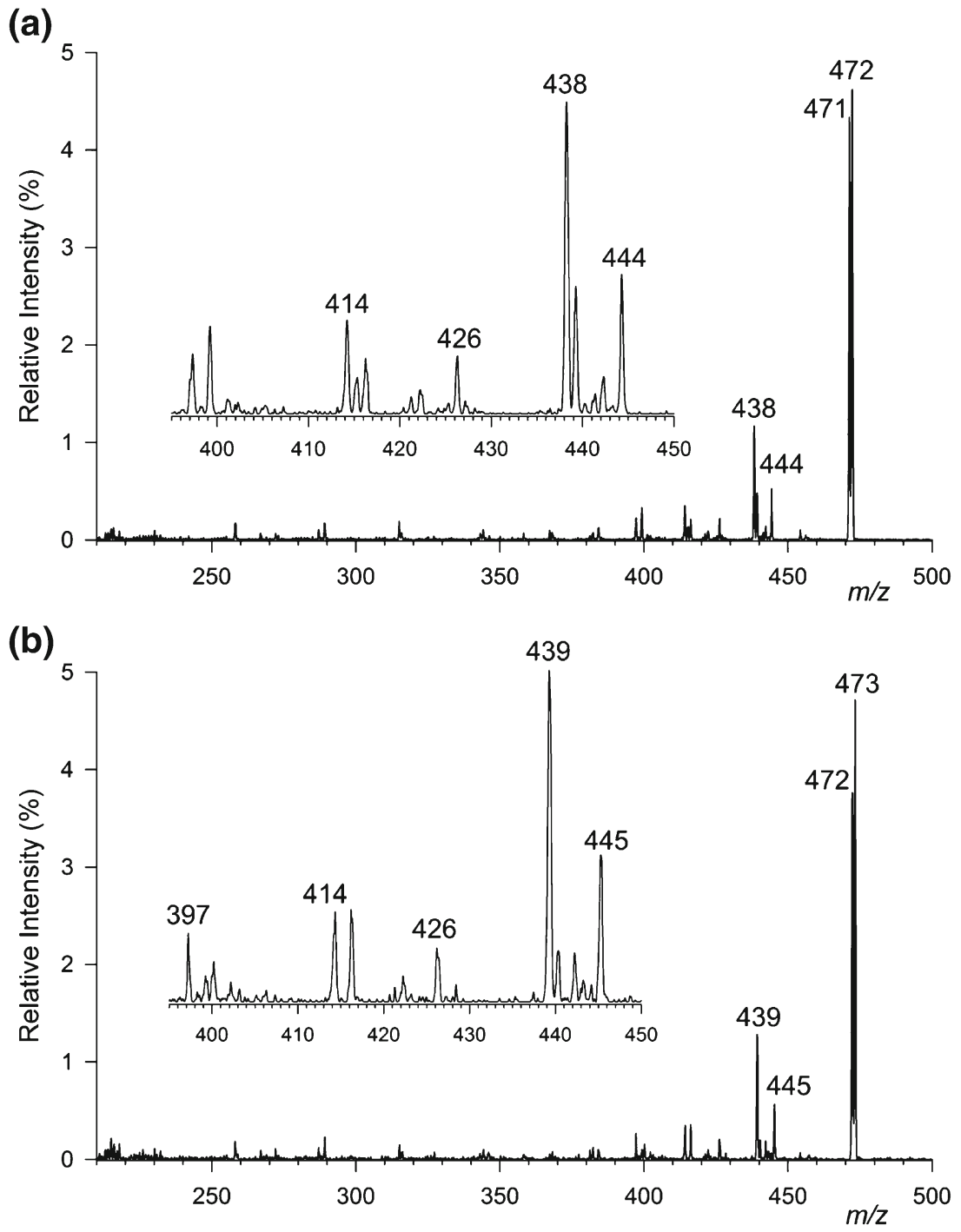

Figure 4. UV photodissociation spectra of (a) mass-selected $\left(\mathrm{GL}{ }^{*} \mathrm{GGR}+2 \mathrm{H}\right)^{+\bullet}$ and $(\mathbf{b})\left({ }^{15} \mathrm{~N}-\mathrm{GL} \mathrm{L}^{*} \mathrm{GGR}+2 \mathrm{H}\right)^{\bullet \bullet}$ ions generated by ETD of doubly charged peptide-crown-ether complexes. Each spectrum was obtained with nine laser pulses 
destruction of the diazirine chromophore upon ETD, as diazirine-containing gas-phase peptide ions are readily photodissociated at $355 \mathrm{~nm}$.

\section{Multistage CID of B Ions}

The $\boldsymbol{B}$ ions by loss of $\mathrm{N}_{2} \mathrm{H}_{2}$ from $(\mathrm{GL} * \mathrm{GGR}+2 \mathrm{H})^{+\bullet}$ were further investigated by CID-MS ${ }^{4}$ combined with isotope labeling. Note that the $\boldsymbol{B}$ ions are cation-radicals that are formed by electron-induced elimination of $\mathrm{N}_{2}$ from the diazirine ring accompanied by transfer of two hydrogen atoms from the peptide exchangeable positions. Detailed description of the experimental results is given in Supplementary Figure S8a-e, and accompanying text in the Supplementary Material. The results can be summarized as follows. The $\boldsymbol{B}$ ions undergo dissociations triggered by radical reactions that are localized in the $\mathrm{Gly}_{1}$ residue and result in eliminations of $\mathrm{HN}=\mathrm{CH}-\mathrm{CO}^{\bullet}, \mathrm{H}_{2} \mathrm{NCH}_{2} \mathrm{CO}^{\bullet}$, and $\mathrm{HN}=\mathrm{CHCONH}_{2}$ neutral radicals and molecules. The $\mathrm{Gly}_{3} \mathrm{Gly}_{4} \mathrm{Arg}$ segment remains largely intact and does not participate in these dissociations. With this in mind, the formation and presumable structures of the $\boldsymbol{B}$ ions are sketched in Scheme 2. The stable $\mathbf{B}_{\mathbf{1}}-\mathbf{B}_{\mathbf{3}}$ ion structures all have the radical in the energetically favorable $\mathrm{Gly}_{1}-\mathrm{C}_{\alpha}, \mathrm{L}^{*}-\mathrm{C}_{\alpha}$, or side-chain allylic positions and, upon collisional activation, undergo radical-induced $\mathrm{CO}-\mathrm{N}$ and $\mathrm{N}-\mathrm{C}_{\alpha}$ bond dissociations accompanied by hydrogen atom migrations that scramble the Gly $\alpha$ hydrogen atoms. Scheme 2 also illustrates the loss upon ETD of the $\mathrm{CH}_{2} \mathrm{NH}_{2}$ radical that originates from the high-energy amidyl $N$-radical, which is likely to rearrange to lower-energy structures in long-lived $\left(\mathrm{GL}^{*} \mathrm{GGR}+2 \mathrm{H}\right)^{+\bullet}$ cation-radicals. This explains why long-lived $\left(\mathrm{GL}^{*} \mathrm{GGR}+2 \mathrm{H}\right)^{+\bullet}$ do not eliminate $\mathrm{CH}_{2} \mathrm{NH}_{2}$ upon collisional activation.

\section{Precursor Ion Structures}

The above-described experimental data indicate that a substantial fraction of $\left(\mathrm{GL}^{*} \mathrm{GGR}+2 \mathrm{H}\right)^{+\bullet}$ cation-radicals undergo dissociations involving the diazirine ring and the $N$-terminal Gly residue. To explain the electronic properties of the reactive cation-radicals that determine the pertinent reaction mechanisms, we undertook a thorough computational study of the precursor ion structures as well as electronic states and dissociation energetics of the cation-radical intermediates. Comprehensive conformational analysis of the gas-phase $(\mathrm{GLGGR}+2 \mathrm{H})^{2+}$ and $(\mathrm{GL} * \mathrm{GGR}+2 \mathrm{H})^{2+}$ ions indicated that the lowenergy conformers share the same folding patterns (Figure S1). A dominant folding motif is characterized by hydrogen bonding of the charged guanidinium group of the Arg side chain to the $\mathrm{Gly}_{3}$ amide oxygen. This feature shows minor variations because of the different dihedral angles in the folding of the connecting Arg side chain that have only small effects on the relative free energies amongst the $(\mathrm{GLGGR}+2 \mathrm{H})^{2+}$ conformers GLGGRa-GLGGRd (Figure S1, Table S1, Supplementary Material). The other dominant feature is the hydrogen bonding of the charged $N$-terminal ammonium group to the carboxyl and Gly 4 amide oxygens that also shows small variations in the orientation of the $\mathrm{COOH}$ group and participation of the $\mathrm{Gly}_{4}$ amide oxygen.

These major structure features were preserved in the lowest-free energy conformers of $(\mathrm{GL} * \mathrm{GGR}+2 \mathrm{H})^{2+}$ $\left(\mathbf{1 a}^{2+}-\mathbf{2} \mathrm{d}^{2+}\right.$, Figure 5). An additional feature introduced by the diazirine ring was the weak hydrogen bonding of the diazirine nitrogens to the sterically accessible $\mathrm{Gly}_{1}$

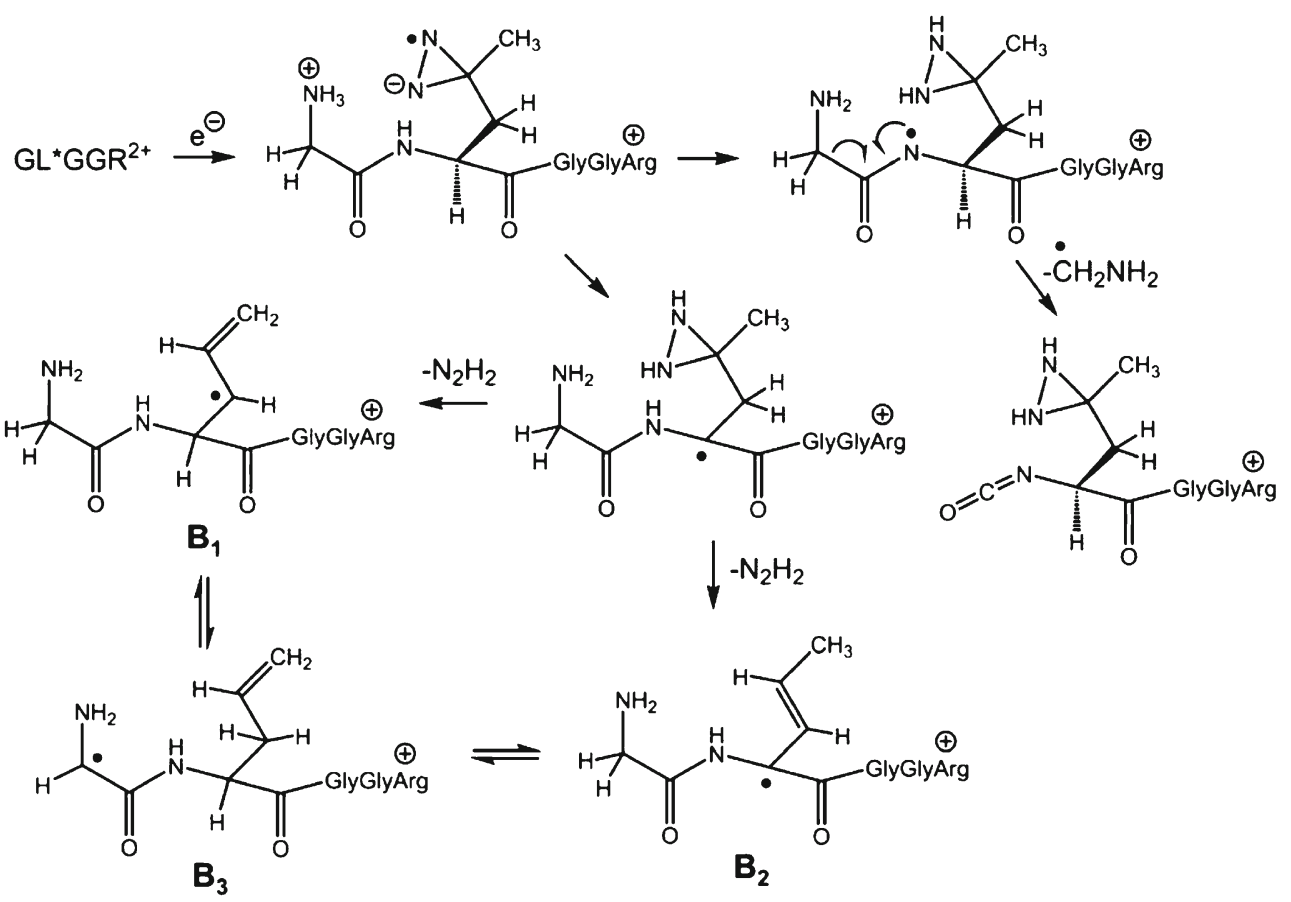

Scheme 2. Dissociations of $\left(G L^{*} G G R+2 H\right)^{+\bullet}$ leading to loss of $\mathrm{N}_{2} \mathrm{H}_{2}$ 

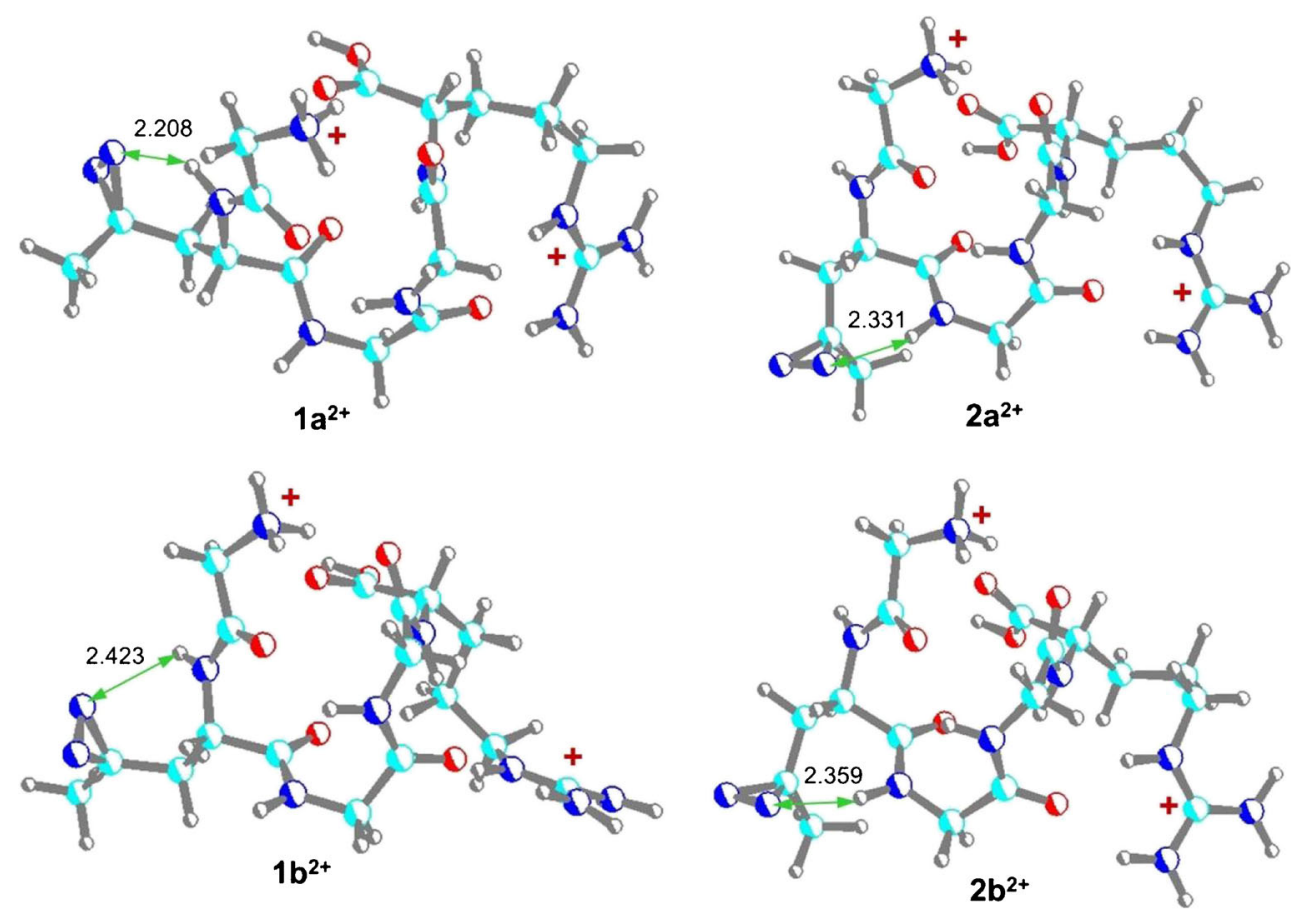

Figure 5. M06-2X/6-31+G(d,p) optimized structures of lowest free-energy conformers of $\left(\mathrm{GL}^{*} \mathrm{GGR}+2 \mathrm{H}\right)^{2+}$ ions. The atom color coding is as follows: turquoise $=\mathrm{C}$, blue $=\mathrm{N}$, red=O, gray $=\mathrm{H}$. Green double-ended arrows indicate the hydrogen bonds to the diazirine ring with distances given in Ångstrøms

and $\mathrm{L}^{*}$ amide $\mathrm{N}-\mathrm{H}$ bonds that determines the orientation of the $\mathrm{L}^{*}$ side chain. These $\mathrm{L}^{*}$ side-chain conformers showed very similar free energies (Table 1) from which the combined molar fractions were calculated as $59 \%$ $\mathbf{1 a}^{2+}-\mathbf{1} \mathbf{d}^{2+}$ and $41 \% \mathbf{2 a}^{2+}-\mathbf{2 d}^{2+}$ at $298 \mathrm{~K}$. Hence, the calculated free energies predict a mixture of very similar conformers coexisting at equilibrium in the gas phase. This computational result was tested by comparing the calculated conformer collision cross-sections $(\Omega)$ with the experimental datum obtained by drift-cell ion mobility measurements in helium $\left(\Omega=140.7 \pm 0.5 \AA^{2}\right.$, Supplementary Material). The calculated collision cross-sections for several $(\mathrm{GL} * \mathrm{GGR}+2 \mathrm{H})^{2+}$ conformers were within $1 \%$ of each other and somewhat dependent on the optimized geometry and the theoretical model (Table S2, Supplementary Material). In general, B3LYP-optimized structures that were treated with the projection average aproximation (PA) method $[45,46]$ gave theoretical crosssections that were $\Omega=142 \pm 0.5 \AA^{2}$. Cross sections based on M06-2X-optimized structures that were treated with the projection average aproximation and ion trajectory method (TM) [47] were $\Omega=136 \pm 1.2 \AA^{2}$ and $144 \pm 1.3 \AA^{2}$, respectively, which bracketted the experimental value. The close agreement between the theoretical and experimental collisional cross

Table 1. Relative Energies of $(\mathrm{GL} * \mathrm{GGR}+2 \mathrm{H})^{2+}$ Dications

\begin{tabular}{|c|c|c|c|c|c|}
\hline \multirow{3}{*}{ Ion } & \multicolumn{5}{|c|}{ Relative energy ${ }^{\mathrm{a}, \mathrm{b}}$} \\
\hline & \multirow{2}{*}{$\frac{\text { B3LYP }}{6-31+G(d, p)}$} & \multirow{2}{*}{$\frac{M 06-2 X}{6-31+G(, p)}$} & B3LYP & \multirow[t]{2}{*}{$\mathrm{MP} 2^{\mathrm{c}}$} & \multirow[t]{2}{*}{ M06- $2 X^{d}$} \\
\hline & & & $6-311++G(2 d, p)$ & & \\
\hline $1 a^{2+}$ & 0.0 & 0.0 & 0.0 & 0.0 & $0.0(0.0)^{\mathrm{e}}$ \\
\hline $1 b^{2+}$ & 1.4 & 0.5 & 0.8 & 2.0 & $-0.4(-2.1)^{\mathrm{e}}$ \\
\hline $1 \mathrm{c}^{2+}$ & 2.7 & -1.7 & 1.5 & 2.5 & $-0.6(-3.1)^{\mathrm{e}}$ \\
\hline $1 \mathrm{~d}^{2+}$ & 1.7 & 0.7 & 1.0 & 2.2 & $0.2(-0.2)^{\mathrm{e}}$ \\
\hline $2 a^{2+}$ & 0.3 & -0.2 & 0.4 & 0.8 & $0.2(-1.2)^{\mathrm{e}}$ \\
\hline $2 b^{2+}$ & 4.5 & -2.0 & 3.2 & 4.6 & $-0.5(-3.2)^{\mathrm{e}}$ \\
\hline $2 c^{2+}$ & -1.0 & 1.1 & 0.1 & -5.9 & $1.6(6.5)^{\mathrm{e}}$ \\
\hline $2 d^{2+}$ & 4.5 & 7.1 & 3.3 & 4.6 & $6.5(3.8)^{\mathrm{e}}$ \\
\hline
\end{tabular}

${ }^{\mathrm{a}}$ In units of $\mathrm{kJ} \mathrm{mol}^{-1}$.

${ }^{\mathrm{b}}$ Including zero-point vibrational energy corrections and referring to $0 \mathrm{~K}$.

${ }^{\mathrm{c}}$ From single-point energy calculations with the $6-311++\mathrm{G}(2 \mathrm{~d}, \mathrm{p})$ basis set using the B3LYP/6-31+G(d,p) optimized geometries.

${ }^{\mathrm{d}}$ From single-point energy calculations with the $6-311++\mathrm{G}(2 \mathrm{~d}, \mathrm{p})$ basis set using the M06-2X/6-31+G(d,p) optimized geometries.

${ }^{\mathrm{e}}$ Relative free energies at $298 \mathrm{~K}$ 
sections indicates that the calculated ion structures accurately represent the ions experimentally studied in the gas phase.

\section{GL*GGR Cation-Radical Structures and Dissociation Mechanisms}

The electronic properties of $(\mathrm{GL} * \mathrm{GGR}+2 \mathrm{H}){ }^{+}$cation-radicals were first addressed by time-dependent DFT calculations in which an electron was attached to the dication at its fixed optimized geometry. This provided vertical recombination energies of the dications (4.9-5.3 eV), as well as the manifolds of electronic states describing the electron-ion interactions. The lowest $(\boldsymbol{X}-\boldsymbol{C})$ electronic states showed combinations of the diazirine $\pi^{*}$ orbital with the orbitals, which are typical of electron attachment to charged peptide groups, e.g., the $\mathrm{N}$ terminal ammonium $3 \mathrm{~s}$ Rydberg ( $\boldsymbol{X}$ state), amide and $\mathrm{COOH}$ $\pi^{*}$ orbitals ( $\boldsymbol{A}$ and $\boldsymbol{C}$ states), and a guanidinium $\sigma^{*}$ orbital $(\boldsymbol{B}$ state) (Figure S9, Supplementary Material) [47]. These results indicated that the electron-ion interaction included a substantial participation by the diazirine $\pi^{*}$ orbital in the initial stages of electron attachment [13].

Full gradient optimization of $(\mathrm{GL} * \mathrm{GGR}+2 \mathrm{H})^{+\bullet}$ cationradical structures resulted in major bonding changes that depended on the backbone folding and orientation of the diazirine side chain. In general terms, conformers $\mathbf{1 a}-\mathbf{1 d}$ rearranged upon electron attachment by spontaneous and highly exothermic transfer of a proton onto the incipient diazirine anion-radical, forming diaziridine radicals 3a-d. Which protons were involved in this rearrangement, (i.e., $\mathrm{N}$-terminal $\mathrm{NH}_{3}, \mathrm{Gly}_{1}$ amide $\mathrm{N}-\mathrm{H}$, or $\mathrm{COOH}$ ), depended on the precursor dication conformation, as detailed by several energetically plausible reaction pathways, which are shown in the Supplementary Material (Scheme S1, S2). Regardless of the detailed isomerization pathways, the proton migration rearrangement was in all cases $>110 \mathrm{~kJ} \mathrm{~mol}^{-1}$ exothermic to contribute to vibrational excitation in intermediates $\mathbf{3 a}-\mathbf{d}$ and drive their further dissociations. This and the following reactions are schematically sketched in Scheme 3. For fully optimized structures of intermediates and transition states, see Schemes S1-S4 in the Supplementary Material. The pertinent energies obtained at several levels of theory are shown in Table 2 and the combined B3LYP and PMP2 values are used for illustration in the text.

The main reaction of $\mathbf{3 a}$ was a ring opening in the diaziridine radicals forming diazene intermediate $\mathbf{4 a}$ that can exothermically refold to $\mathbf{4 b}$ (Scheme S3, Supplementary Material). Note that for the sake of simplicity these intermediates are sketched as a single structure $\mathbf{4 a , b}$ in Scheme 3. The pertinent TS (TS1) was $101 \mathrm{~kJ} \mathrm{~mol}^{-1}$ relative to 3a (Table 2), and the ring opening was $76 \mathrm{~kJ} \mathrm{~mol}^{-1}$ exothermic when taking into account the conformational refolding to $\mathbf{4 b}$ in order to establish favorable hydrogen bonding to the diazene group. Diazenes $\mathbf{4 a}, \mathbf{b}$ have a $\pi$-conjugated $\mathrm{HN}=\mathrm{N}-\mathrm{C}$ radical moiety that may be further stabilized by abstracting a labile hydrogen atom. TS2 describes a transition state for the migration of an $\mathrm{L}^{*}$

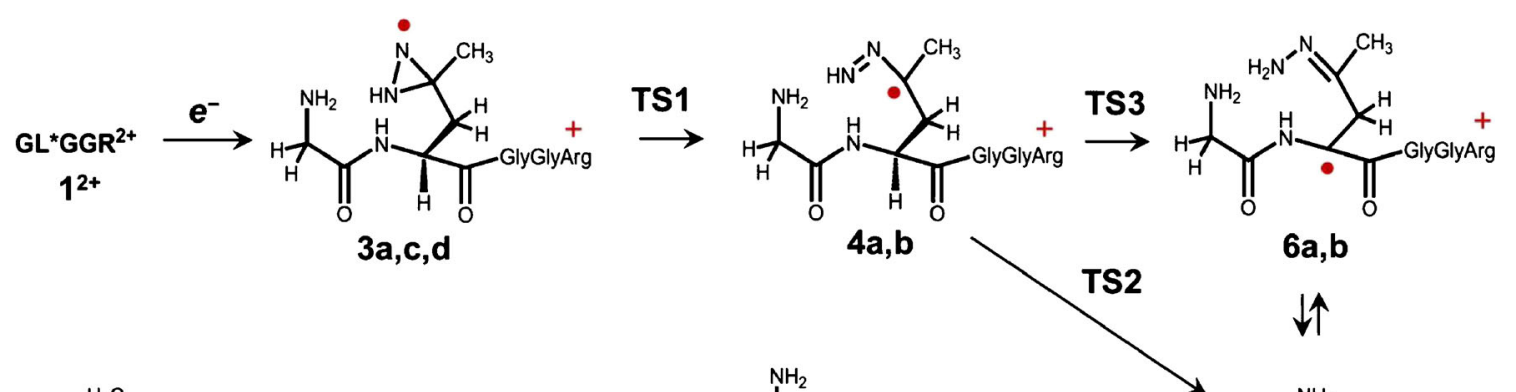<smiles>CCC(C)(C)[Si](C)(C)C</smiles>

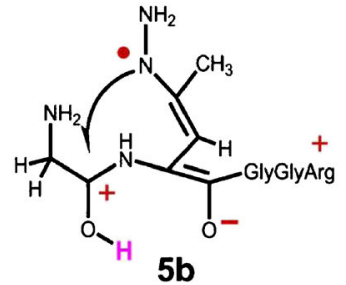

$\stackrel{\text { TS4 }}{\longleftarrow}$<smiles>C/C(=C\C1(C(=O)O[Na])NCCOC1CN)NN</smiles>

5<smiles>CCOC(=O)C1=CC(C)=N[C@](O)(CN)N1</smiles><smiles></smiles>

9<smiles></smiles>

A (10)

Scheme 3. Dissociations of $\left(\mathrm{GL}^{*} \mathrm{GGR}+2 \mathrm{H}\right)^{+\bullet}$ leading to loss of $\left[\mathrm{NH}_{4} \mathrm{O}\right]$ 
Table 2. Relative Energies of GL*GGR Cation-Radicals

\begin{tabular}{|c|c|c|c|c|c|}
\hline \multirow[b]{2}{*}{ Species/reaction } & \multicolumn{5}{|c|}{ Relative energy $\mathrm{y}^{\mathrm{a}, \mathrm{b}}$} \\
\hline & ${\mathrm{B} 3 \mathrm{LYP}^{c}}$ & $\mathrm{PMP}^{\mathrm{c}, \mathrm{d}}$ & B3-PMP2 ${ }^{\mathrm{e}}$ & $\omega \mathrm{B} 97 \mathrm{XD}^{c}$ & M06- $2 X^{f}$ \\
\hline $3 a$ & 0 & 0 & 0 & 0 & 0 \\
\hline $3 b$ & 79 & 73 & 76 & - & 81 \\
\hline $3 \mathrm{c}$ & -0.6 & 7 & 3 & - & -5 \\
\hline $3 d$ & -2 & 4 & 1 & 3 & -5 \\
\hline $4 a$ & 58 & 114 & 86 & 80 & 81 \\
\hline $4 b$ & -80 & -73 & -76 & -73 & -71 \\
\hline 5 & -101 & -85 & -94 & -79 & -81 \\
\hline $5 b$ & -16 & 31 & 7 & 40 & 31 \\
\hline $6 \mathrm{a}$ & -90 & -62 & -76 & -61 & -60 \\
\hline $6 \mathrm{~b}$ & -81 & -61 & -71 & -54 & -57 \\
\hline $7 \mathrm{a}$ & -54 & -52 & -53 & -39 & -52 \\
\hline $7 \mathrm{~b}$ & -84 & -82 & -83 & -73 & -92 \\
\hline 8 & -56 & -46 & -51 & -17 & -20 \\
\hline $9+\mathrm{NH}_{2}$ & -32 & -26 & -29 & 5 & 5 \\
\hline $10+\mathrm{NH}_{2}+\mathrm{H}_{2} \mathrm{O}$ & -60 & -41 & -51 & 14 & 6 \\
\hline TS1 & 97 & 104 & 101 & 114 & 123 \\
\hline TS2 & 119 & 102 & 110 & 125 & 125 \\
\hline TS3 & 70 & 71 & 70 & 88 & 92 \\
\hline TS4 & 26 & 59 & 43 & 66 & 60 \\
\hline TS5 & 19 & 54 & 36 & 68 & 41 \\
\hline TS6 & - & - & - & - & 123 \\
\hline TS7 & 8 & 21 & 14 & 48 & 50 \\
\hline 11 & 170 & 154 & 162 & 181 & 162 \\
\hline 12 & 112 & 92 & 102 & 119 & 108 \\
\hline 13 & 115 & 117 & 116 & 121 & 113 \\
\hline 14 & 133 & 115 & 124 & 140 & 105 \\
\hline 15 & 204 & 166 & 185 & 203 & 182 \\
\hline 16 & 146 & 118 & 132 & 140 & 129 \\
\hline
\end{tabular}

${ }^{\mathrm{a}}$ In units of $\mathrm{kJ} \mathrm{mol}^{-1}$.

${ }^{\mathrm{b}}$ Including zero-point vibrational energy corrections and referring to $0 \mathrm{~K}$.

${ }^{\mathrm{c}}$ From single-point energy calculations with the 6-311++G(2d,p) basis set using the B3LYP/6-31+G(d,p) optimized geometries.

${ }^{\mathrm{d}}$ From spin-projected single point MP2/6-311++G(2d,p) energies.

${ }^{\mathrm{e}}$ From combined B3LYP and PMP2/6-311++G(2d,p) single-point energy calculations.

${ }^{\mathrm{f}}$ From single-point energy calculations with the $6-311++\mathrm{G}(2 \mathrm{~d}, \mathrm{p})$ basis set using the M06-2X/6-31+G(d,p) optimized geometries.

$\beta$-hydrogen atom in $\mathbf{4 a}$, exothermically forming radical $\mathbf{5}$ (Scheme 3). The energy of TS2 (110 kJ mol ${ }^{-1}$, Table 2) is slightly higher than that for TS1. An alternative pathway is through TS3, which describes transfer of the $\mathrm{L}^{*} \mathrm{C}_{\alpha}$ hydrogen to form the $\mathrm{L}^{*}-\mathrm{C}_{\alpha}$ radicals $\mathbf{6 a}, \mathbf{b}$ (Scheme S4, Supplementary Material). The energy of TS3 $\left(70 \mathrm{~kJ} \mathrm{~mol}^{-1}\right.$, Table 2$)$ is below that for TS1, and the $\mathrm{L}^{*} \alpha$-hydrogen migration to form radical 5 is nearly thermoneutral.

The next step is a pseudo-pericyclic reaction whereby the $\mathrm{NH}_{2}-\mathrm{N}$ group in $\mathbf{5}$ attacks the Gly amide carbonyl, forming conformers of cyclic intermediates 7a,b (Scheme 4). Extensive mapping of the potential energy surface for the $\mathbf{5} \rightarrow \mathbf{7 a}, \mathbf{b}$ reaction revealed that it preferentially proceeds in two steps. The first step is a proton migration from the $\mathrm{L}^{*} \mathrm{C}_{\alpha}$ position onto the $\mathrm{Gly}_{1}$ amide oxygen. The migration is facilitated by the diazaallyl radical group in the side chain to proceed through a low-energy TS4, which was $134 \mathrm{~kJ} \mathrm{~mol}^{-1}$ above 5 but only $43 \mathrm{~kJ} \mathrm{~mol}^{-1}$ relative to $\mathbf{3 a}$ (Table 2). In contrast, a pseudoconcerted reaction involving a single-step hydrogen transfer and ring closure was found to face a substantial energy barrier (TS6), as also shown in the B3LYP/6-31+G(d,p) map of the potential energy surface in Figure S10 (Supplementary Material). Intrinsic reaction coordinate analysis [48] connects TS4 with another intermediate (5b). Its optimized structure (Scheme 4) shows a planar aminoketyl group and short $\mathrm{C}-\mathrm{O}$ and $\mathrm{C}-\mathrm{N}$ bonds that indicate that $\mathbf{5 b}$ is not a proper aminoketyl radical [49], but rather an unusual zwitterion consisting of an O-protonated $\mathrm{Gly}_{1}$ amide and an extended $\pi$-conjugated $\mathrm{H}_{2} \mathrm{~N}$ $\mathrm{N}^{\bullet}-\mathrm{C}\left(\mathrm{CH}_{3}\right)=\mathrm{CH}-\mathrm{C}(\mathrm{R})-\mathrm{C}-\mathrm{O}^{-}$anion-radical system. The subsequent six-membered ring closure, whereby the $\mathrm{NH}_{2}-\mathrm{N}$ group attacks the $\mathrm{Gly}_{1}$ amide carbon, can be viewed as an anionradical-cation recombination reaction, proceeding through $\mathbf{T S 5}$ at $29 \mathrm{~kJ} \mathrm{~mol}^{-1}$ relative to $\mathbf{5 b}$. Note that the TS5 energy is only $36 \mathrm{~kJ} \mathrm{~mol}^{-1}$ relative to $\mathbf{3 a}$ (Table 2) and the cyclization in $\mathbf{5 b}$ is $60 \mathrm{~kJ} \mathrm{~mol}^{-1}$ exothermic (Table 2), allowing for a facile reaction. The cyclized radicals $\mathbf{7 a}, \mathbf{b}$ are energetically plausible species $\left(-53\right.$ to $-83 \mathrm{~kJ} \mathrm{~mol}^{-1}$ relative to 3a) that can be readily linked to further dissociations resulting in the loss of $\left[\mathrm{NH}_{4} \mathrm{O}\right]$ as $\mathrm{NH}_{2}$ and $\mathrm{H}_{2} \mathrm{O}$. This presumably starts with a $\mathrm{N}-\mathrm{N}$ bond cleavage through TS7 $\left(14 \mathrm{~kJ} \mathrm{~mol}^{-1}\right.$ relative to 3a), forming a complex with $\mathrm{NH}_{2}{ }^{\bullet}(\mathbf{8})$. The latter then undergoes slightly endothermic dissociation by loss of $\mathrm{NH}_{2}$ radical forming ion 9. Elimination of water from 9 is exothermic and forms the aromatic pyrimidine ring in 10, which corresponds to fragment $\boldsymbol{A}$ in the ETD mass spectrum. 

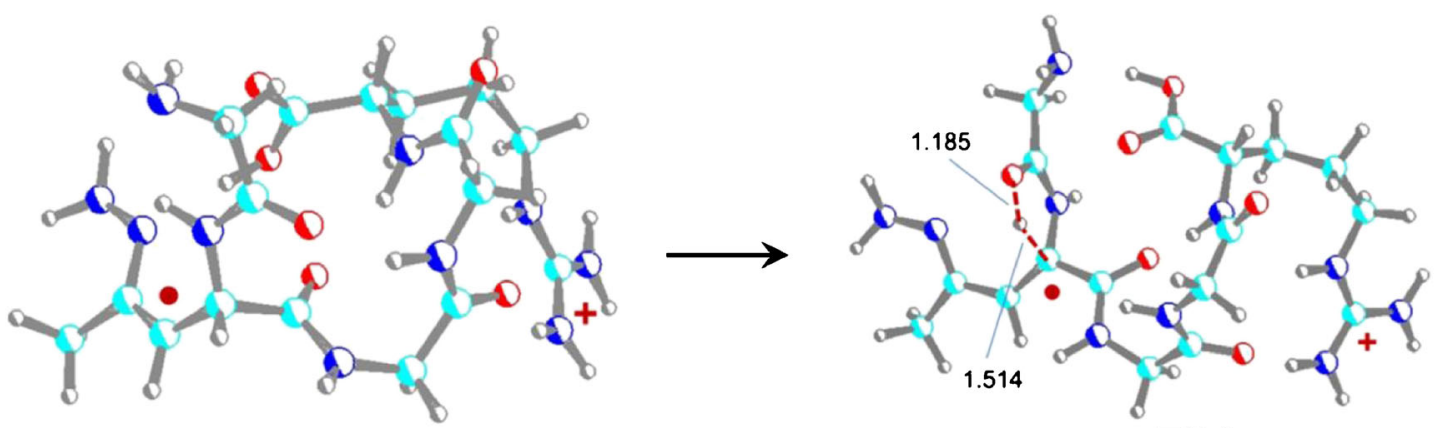

\section{5}

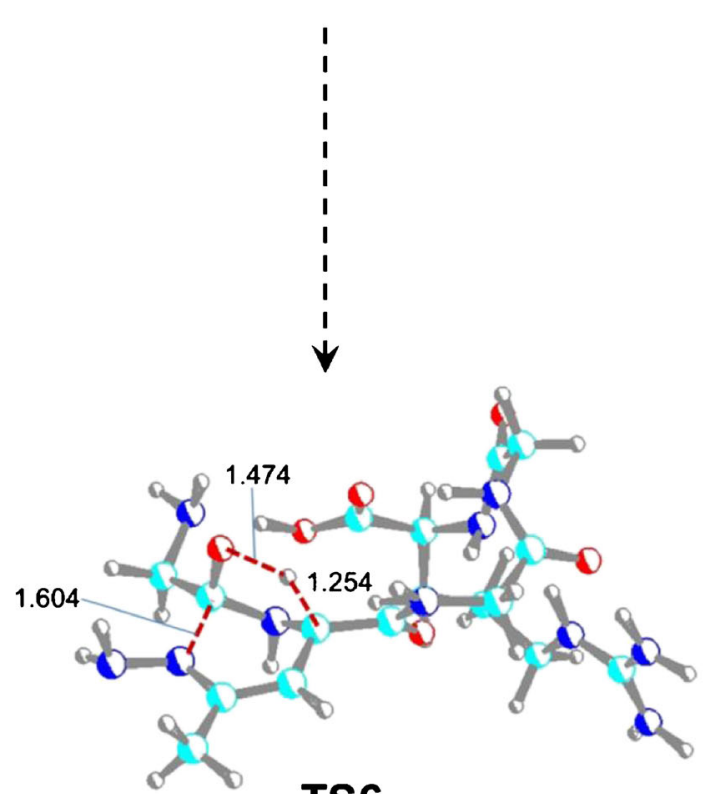

TS6

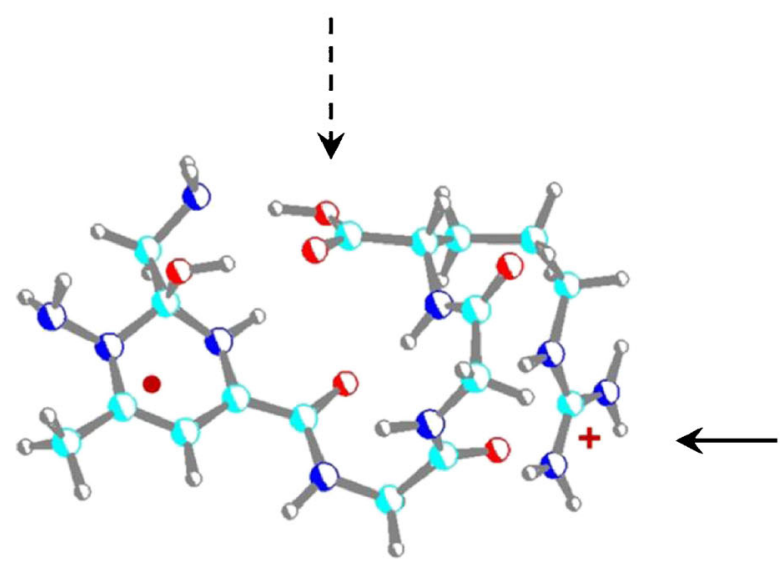

7b
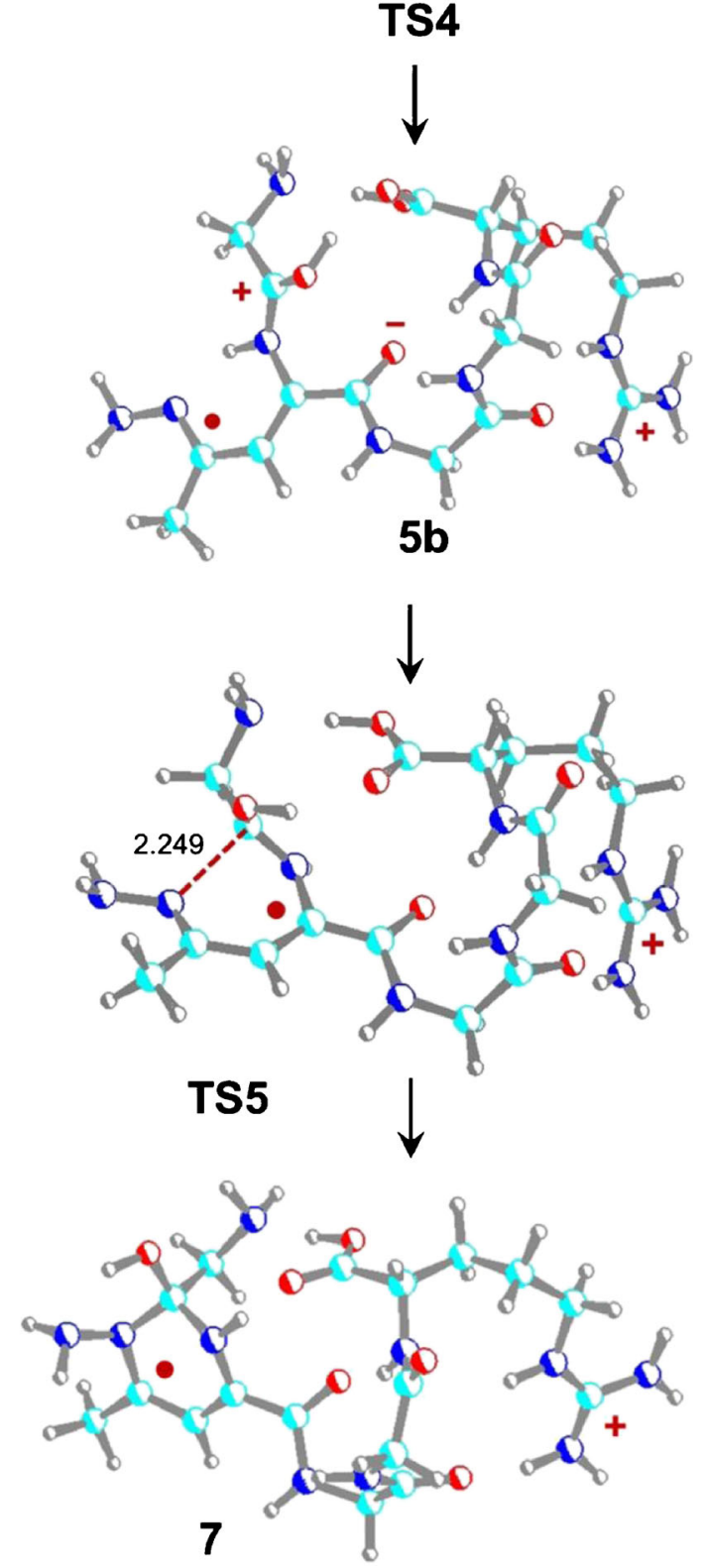

Scheme 4. Isomerization and cyclization in imine radical 5 showing fully optimized M06-2X/6-31+G(d,p) structures

To further characterize structure 10, we measured the

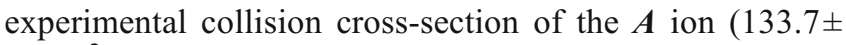
$0.3 \AA^{2}$, Table S2) and compared it with the value calculated by the ion trajectory method for the M06-2X optimized ion structure $\left(133.8 \AA^{2}\right)$. The excellent agreement corroborates our assignment of ion $\boldsymbol{A}$ as having the cyclic structure $\mathbf{1 0}$.

Conformers $2 \mathbf{a}^{2+}-\mathbf{2} \mathbf{d}^{2+}$ were calculated to comprise a substantial population of gas-phase $(\mathrm{GL} * \mathrm{GGR}+2 \mathrm{H})^{2+}$ ions, and therefore cation-radicals formed upon their charge reduction 
were of interest. Electron attachment followed by gradient optimization of $(\mathrm{GL} * \mathrm{GGR}+2 \mathrm{H})^{+\bullet}$ resulted in several structures depending on the precursor dication conformation. Zwitterionic cation radical 11 (Figure S11, Supplementary Material) resulted as a local energy mininum upon electron attachement to the Gly ${ }_{1}$ amide $\pi^{*}$ orbital. In another structure, ammonium proton migration onto the $\mathrm{COOH}$ group formed a $\mathrm{C}(\mathrm{OH})_{2}$ radical group (12). In yet another structure, $\mathrm{L}^{*}$ amide proton migration onto the diazirine anion-radical formed the zwitterionic diazirine radical 13. A common feature of these cationradical structures was that they had substantially higher potential energies than 3 (Table 2). Presumably, these high-energy species isomerized to $\mathbf{3 a}$ or its conformers by exothermic proton or hydrogen atom transfer and further dissociated along the pathways shown in Schemes 2 and 3.

Relatively high potential energies were also calculated for proper aminoketyl radicals [49] with reduced $\mathrm{Gly}_{1}, \mathrm{Gly}_{3}$, and $\mathrm{Gly}_{4}$ amide groups (14-16) that were the presumed reactive intermediates of $\mathrm{N}-\mathrm{C}_{\alpha}$ bond cleavages leading to the formation of sequence $z$ fragment ions (Figure S12, Supplementary Material). This feature will be discussed in more detail below.

\section{Discussion}

Analysis of the experimental ETD data indicated that there were two kinds of populations of charge-reduced cationradicals that differed in reactivity. The major population of charge-reduced $\left(\mathrm{GL}^{*} \mathrm{GGR}+2 \mathrm{H}\right)^{+\bullet}$ cation-radicals (up to $75 \%$ ) undergo loss of ammonia and backbone dissociations forming the $\boldsymbol{z}_{1}-\boldsymbol{z}_{\mathbf{4}}$ fragment ions. These are typical dissociations of standard peptide ions that are triggered by electron attachment. The unusual feature of ETD of the diazirine-tagged peptides is the dissociations of a population of cation-radicals originating by electron attachment to the diazirine ring that amount up to $40 \%$ of the respective radical reactions of $(\mathrm{GL} * \mathrm{GGR}+2 \mathrm{H})^{+\bullet}$. This fraction further increases up to $80 \%$ when the electron attachment occurs in peptide ion-crown ether complexes. The fact that $\left(\mathrm{GL}^{*} \mathrm{GGR}+2 \mathrm{H}\right)^{+\bullet}$ cationradicals generated this way are stable can be attributed to (1) the specifics of their structure, (2) the peptide-crown complex dissociation energy, and (3) the degree of freedom effect whereby a 38\%-39\% portion of excitation energy deposited by electron attachment into the complex is carried away by the crown ether molecule. Furthermore, the recombination energy (RE) of the peptide ion in the crown ether complex is likely to be lower than that of the peptide dication because of two factors [50]. One is the substantial stabilization of the peptide charged group, which binds the crown-ether molecule (e.g., 170$280 \mathrm{~kJ} \mathrm{~mol}^{-1}$ for alkylammonium and diammonium complexes [51-53]). This lowers the potential energy of the complex in the precursor ion, $\mathrm{E}$ (dication), but does not affect much the potential energy of the charge-reduced complex, E(cation-radical), so the absolute value of $\mathrm{RE}=\mathrm{E}$ (dication) $-\mathrm{E}$ (cationradical) decreases. The other factor is due to conformational changes in the peptide ion upon crown ether binding. The oxygens of the crown ether molecule provide electron donors to form hydrogen bonds to the protonated peptide group, which disrupts its hydrogen bonding to the peptide donor groups and results in partial unfolding of the peptide ion. This in turn results in a greater separation of the peptide charge-carrying groups in the complex, thus diminishing the Coulomb energy released upon charge reduction, which is an important component of recombination energy of multiply charged ions [54].

The salient and puzzling feature of ETD of the diazirinetagged peptides is not that the diazirine-triggered dissociations occur, but that they occur to only $40 \%$. This presents an apparent discrepancy between the potential energies of the isomeric charge-reduced species and their populations undergoing backbone and diazirine-triggered dissociations. According to the calculated relative energies of isomeric (GL*GGR $+2 \mathrm{H})^{+\bullet}$ cation-radicals on the ground doublet potential energy surface (Table 2), the diaziridine-related radicals $\mathbf{3 a}-\mathbf{7 a}$ are substantially more thermodynamically stable than aminoketyl radicals (14-16), which are the presumed reactive intermediates of backbone $\mathrm{N}-\mathrm{C}_{\alpha}$ dissociations [55]. If all these species, 3a-7a and 14-16, were to equilibrate on the ground state potential energy surface, no aminoketyl radicals would be populated at all. The lowest-energy aminoketyl radical (14 at $124 \mathrm{~kJ} \mathrm{~mol}^{-1}$ relative to 3a) can hardly at all be formed from $\mathbf{3 a}$ in competition with the highly exothermic ring opening to $\mathbf{4 b}$ that requires a TS1 energy of $101 \mathrm{~kJ} \mathrm{~mol}^{-1}$. Furthermore, ion 14 is an intermediate for the $z_{4}$ fragment ion, which is very minor in the ETD mass spectrum. These considerations lead to the conclusion that the side-chain and backbone dissociations upon ETD of the diazirine-tagged peptide ions originate from distinct, non-interconverting, electronic states. The electronic states involving the diazirine ring are indicated in the orbital diagrams for vertically reduced $\left(\mathrm{GL}^{*} \mathrm{GGR}+2 \mathrm{H}\right)^{+\bullet}$ (Figure S9, Supplementary Material). The electronic states leading to backbone cleavages are represented by orbitals showing large amide $\pi^{*}$ components. Gradient optimization of the ground doublet states leads unambiguously to diazirine radicals. This indicates that the backbone dissociations start from excited electronic states. The nature and extent of diazirine-triggered side-chain dissociations depend on the peptide ion composition and sequence. For example, the major diazirine side-chain dissociations by loss of $\mathrm{N}_{2} \mathrm{H}_{2}, \mathrm{~N}_{2} \mathrm{H}_{4}$, and $\left[\mathrm{NH}_{4} \mathrm{O}\right]$ show different relative intentisities in ETD of $\mathrm{L}^{*}$ containing ion from GL*GGK, GL*GLK, GL*LGK [13], and GL*GGR. This indicates that the peptide ion conformation exerts an effect on the competing radical reactions of the diaziridinyl radicals invoving interactions with the Gly ${ }_{1}$ and $\mathrm{L}^{*}$ residues.

The role of the diazirine ring as a backbone cleavage disruptor is not unique. Other functional groups that work as disruptors have been previously identified (e.g., aromatic amino acid residues furnished with $\mathrm{NO}_{2}$ or $\mathrm{CN}$ substituents [5658], thioxoamide groups [59], or fixed charge tags [60]). Conversely, some side-chain dissociations upon electron capture have been identified on the basis of thermochemical arguments as originating from excited electronic states accessed by electron attachment [61]. 

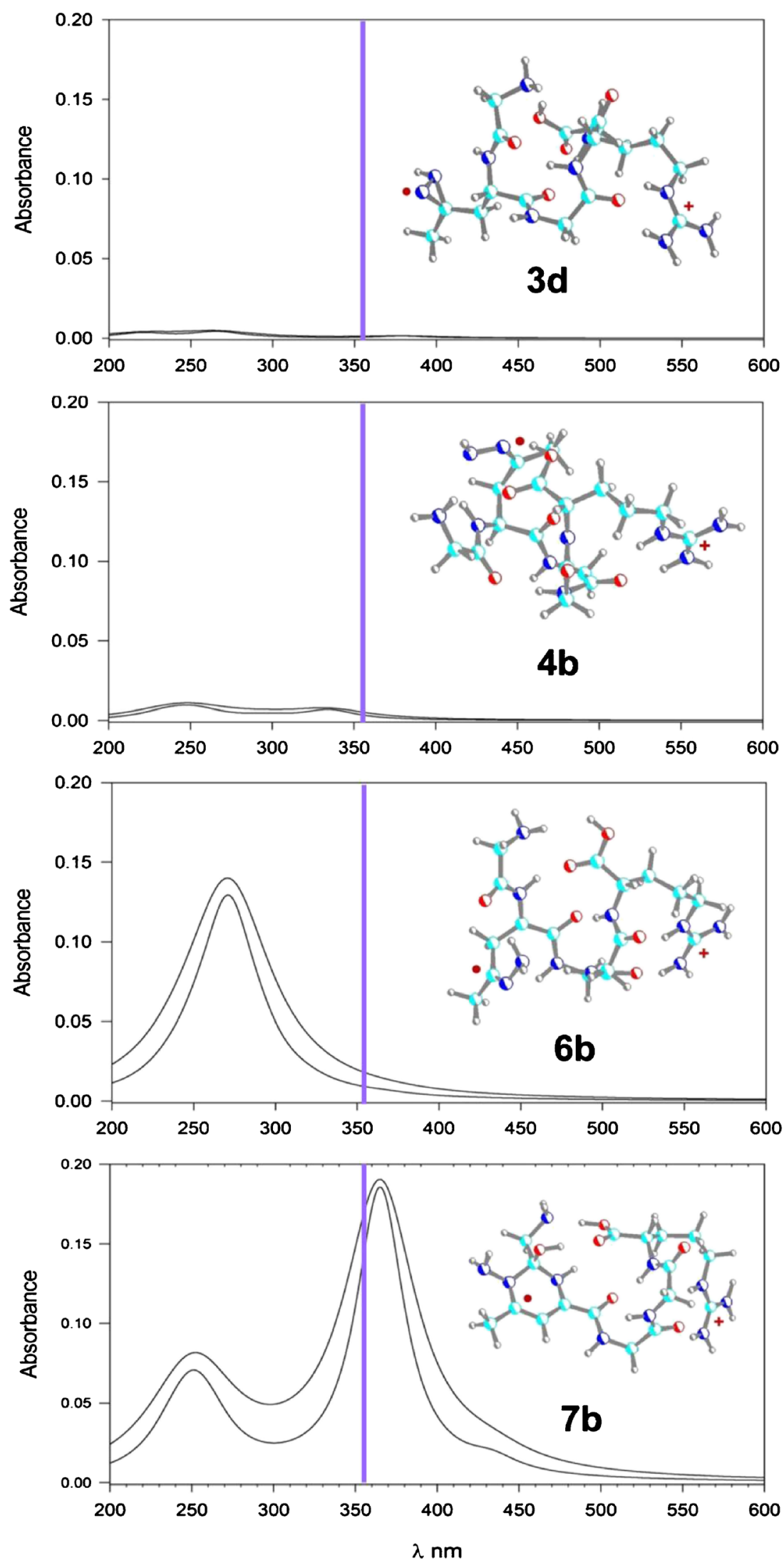

Figure 6. UV spectra from TD-DFT $\omega B 97 X D / 6-311++G(2 d, p)$ calculations plotted on the same absorbance scale. The absorption bands were artificially broadened to 20 and $30 \mathrm{~nm}$. The purple bars indicate the $355 \mathrm{~nm}$ laser excitation wavelength. For details, see Table S3 (Supplementary Material) 
Finally, we address the nature of the stable $(\mathrm{GL} * \mathrm{GGR}+2 \mathrm{H})^{+\bullet}$ cation-radicals that were probed by UVPD showing that they absorb at $355 \mathrm{~nm}$. The observed photodissociation (Figure 4) was chiefly proceeding by radical reactions, indicating that electron transfer produced new chromophores in the charge-reduced ions with absorption in the near UV region. This experimental finding can be related to the calculated resonant electronic transitions in the postulated intermediates 3d, 4a, 6b, and $\mathbf{7 b}$ (Figure 6). The initially formed diaziridinyl radical $\mathbf{3 d}$ is expected to absorb only weakly at $355 \mathrm{~nm}$ due to both the red shift of its transition $(380 \mathrm{~nm})$ and low oscillator strength, $\mathrm{f}=$ 0.003 , which is equivalent to $\varepsilon_{\max } \approx 100 \mathrm{~mol}^{-1} \mathrm{~L} \mathrm{~cm}^{-1}$ [62]. A stronger absorption at the $355 \mathrm{~nm}$ laser line is expected for structures $4 \mathbf{a}$ and $\mathbf{6} \mathbf{b}$ because of a combination of closer match of their resonant transition wavelengths and greater oscillator strengths. A particularly strong absorption is expected for the cyclic intermediates 7a,b which belong to the lowest-energy intermediates. The UVPD data and analysis of electronic transitions indicate that the diaziridinyl radicals $\mathbf{3 a}-\mathbf{d}$ formed by electron attachment and proton migration have rearranged by ring opening and hydrogen atom transfers to reach stable C-centered radicals 5-7. Distinction of structures 5-7 would require wavelengthresolved UV spectroscopic data. Experiments to this end are in progress in this laboratory.

\section{Conclusions}

The experimental and theoretical data reported here allow us to arrive at the following conclusions. Electron transfer to diazirine-tagged peptide ions containing the photoleucine residue results in diazirine ring reduction and formation of radical intermediates in a large fraction of charge-reduced ions. The extent of diazirine reduction is further amplified in ETD of peptide ion complexes with 18-crown-6-ether that provide a convenient means of generating long-lived peptide cation-radicals. The course of diazirine radical reactions depends on the peptide sequence, type of charge-carrying amino acid residues (Lys or Arg), and the photoactive residue side chain. Through a combination of isotope labeling, $\mathrm{MS}^{\mathrm{n}}$, near-UV photodissociation, ion mobility, and electron structure theory calculations, we were able to identify the dissociation products, suggest and characterize several reactive intermediates, and discuss the electronic states involved in electron transfer. The most salient experimental result is the discovery of new chromophores that are produced by electron transfer and absorb light in the near UV region. A comparison of electronic properties of charge-reduced peptide ions leads us to conclude that the traditional ETD cleavages of backbone $\mathrm{N}-\mathrm{C}_{\alpha}$ bonds do not proceed from the ground electronic states of the peptides under study but, instead, involve noninterconverting excited electronic states.

\section{Acknowledgments}

The authors acknowledge financial support provided by the Chemistry Division of the NSF, grants CHE-1055132 and CHE-1359810. F.T. thanks the Klaus and Mary Ann Saegebarth Endowment for support. Technical advice from James Gladden (University of Washington), Drs. Joshua J. Coon (University of Wisconsin), Graeme McAlister, and John E. P. Syka (both ThermoElectron Fisher) is gratefully acknowledged. K.S. acknowledges the support by the Operational Program Research and Development for InnovationsEuropean Regional Development Fund and by the Operational Program Education for Competitiveness-European Social Fund (projects CZ.1.05/2.1.00/03.0058 and CZ.1.07/2.3.00/20.0058 of the Ministry of Education, Youth, and Sports of the Czech Republic).

\section{References}

1. Liu, M.T.H.: Chemistry of Diazirines, vol. I and II. CRC Press, Boca Raton (1987)

2. Frey, H.M., Stevens, I.D.R.: The photolysis of dimethyldiazirine. J. Chem. Soc. 3514-3519 (1963)

3. Amrich, M.J., Bell, J.A.: Photoisomerization of diazirine. J. Am. Chem. Soc. 86, 292-293 (1964)

4. von Doering, W.E., Knox, L.H.: Comparative reactivity of methylene, carbomethoxycarbene, and dicarbethoxycarbene toward the saturated carbon-hydrogen bond. J. Am. Chem. Soc. 83, 1989-1992 (1961)

5. Brunner, J., Senn, H., Richards, F.M.: 3-Trifluoromethyl-3phenyldiazirine. A new carbene generating group for photolabeling reagents. J. Biol. Chem. 255, 3313-3318 (1980)

6. Kumar, A.B.., Anderson, J.M., Manetsch, R.: Design, synthesis and photoactivation studies of fluorous photolabels. Org. Biomol. Chem. 9, 6284-6292 (2011)

7. Hashimoto, M., Hatanaka, Y.: Recent progress in diazirine-based photoaffinity labeling. Eur. J. Org. Chem. 2513-2523 (2008)

8. Das, J.: Aliphatic diazirines as photoaffinity probes for proteins: recent developments. Chem. Rev. 111, 4405-4417 (2011)

9. Dubinsky, L., Bastiaan, P., Krom, B.P., Meijler, M.M.: Diazirine based photoaffinity labeling. Bioorg. Med. Chem. 20, 554-570 (2012)

10. Suchanek, M., Radzikowska, A., Thiele, C.: Photo-leucine and photomethionine allow identification of protein-protein interactions in living cells. Nat. Methods 2, 261-268 (2005)

11. Marek, A., Turecek, F.: Collision-induced dissociation of diazirine-labeled peptide ions. Evidence for brønsted-acid assisted elimination of nitrogen. J. Am. Soc. Mass Spectrom. 25, 778-789 (2014)

12. Elson, C.M., Liu, M.T.H., Mailer, C.E.S.R.: Studies of diazirine anion radicals. J. Chem. Soc., Chem. Commun. 504-506 (1986)

13. Marek, A., Pepin, R., Peng, B., Laszlo, K.J., Bush, M.F., Tureček, F.: Electron transfer dissociation of photolabeled peptides. Backbone cleavages compete with diazirine ring rearrangements. J. Am. Soc. Mass Spectrom. 24, 1641-1653 (2013)

14. Nguyen, H.T.H., Shaffer, C.J., Ledvina, A.R., Coon, J.J., Tureček, F.: Serine effects on collision-induced dissociation and photodissociation of peptide cation radicals of the $\mathrm{z}^{+\bullet}$-type. Int. J. Mass Spectrom. (2014). doi:10.1016/j.ijms.2014.06.028

15. Janz, J.M., Ren, Y., Looby, R., Kazmi, M.A., Sachdev, P., Grunbeck, A., Haggis, L., Chinnapen, D., Lin, A.Y., Seibert, C., McMurry, T., Carlson, K.E., Muir, T.W., Hunt, S., Sakmar, T.P.: Direct interaction between an allosteric agonist pepducin and the chemokine receptor CXCR4. J. Am. Chem. Soc. 133, 15878-15881 (2011)

16. Coste, J., LeNguyen, D., Castro, B.: PyBOP@: A new peptide coupling reagent devoid of toxic by-product. Tetrahedron Lett. 31, 205-208 (1990)

17. Pringle, S.D., Giles, K., Wildgoose, J.L., Williams, J.P., Slade, S.E., Thalassinos, K., Bateman, R.H., Bowers, M.T., Scrivens, J.H.: An investigation of the mobility separation of some peptide and protein ions using a new hybrid quadrupole/traveling wave IMS/oa-ToF instrument. Int. J. Mass Spectrom. 261, 1-10 (2007) 
18. Giles, K., Williams, J.P., Campuzano, I.: Enhancements in traveling wave ion mobility resolution. Rapid Commun. Mass Spectrom. 25, 1559-1566 (2011)

19. Pepin, R., Laszlo, K.J., Peng, B., Marek, A., Bush, M.F., Tureček, F.: Comprehensive analysis of Gly-Leu-Gly-Gly-Lys peptide dication structures and cation-radical dissociations following electron transfer: from electron attachment to backbone cleavage, ion-molecule complexes, and fragment separation. J. Phys. Chem. A 118, 308-324 (2014)

20. Ledvina, A.R., Beauchene, N.A., McAlister, G.C., Syka, J.E.P., Schwartz, J.C., Griep-Raming, J., Westphall, M.S., Coon, J.J.: Activated-ion electron transfer dissociation improves the ability of electron transfer dissociation to identify peptides in a complex mixture. Anal. Chem. 82, 10068-10074 (2010)

21. Moss, C.L., Chung, T.W., Wyer, J.A., Nielsen, S.B., Hvelplund, P., Tureček, F.: Dipole-guided electron capture causes abnormal dissociations of phosphorylated pentapeptides. J. Am. Soc. Mass Spectrom. 22, 731-751 (2011)

22. Moss, C.L., Chamot-Rooke, J., Brown, J., Campuzano, I., Richardson, K., Williams, J., Bush, M., Bythell, B., Paizs, B., Tureček, F.: Assigning structures to gas-phase peptide cations and cation-radicals. An infrared multiphoton dissociation, ion mobility, electron transfer, and computational study of a histidine peptide ion. J. Phys. Chem. B 116, 3445-3456 (2012)

23. Sugita, Y., Okamoto, Y.: Replica-exchange molecular dynamics method for protein folding. Chem. Phys. Lett. 314, 141-151 (1999)

24. Phillips, J.C., Braun, R., Wang, W., Gumbart, J., Tajkhorshid, E., Villa, E., Chipot, C., Skeel, R.D., Kale, L., Schulten, K.: Scalable molecular dynamics with NAMD. J. Comp. Chem. 26, 1781-1802 (2005)

25. MacKerell Jr., A.D., Bashford, D., Bellott, M., Dunbrack Jr., R.L., Evanseck, J.D., Field, M.J., Fischer, S., Gao, J., Guo, H., Ha, S., JosephMcCarthy, D., Kuchnir, L., Kuczera, K., Lau, F.T.K., Mattos, C., Michnick, S., Ngo, T., Nguyen, D.T., Prodhom, B., Reiher III, W.E., Roux, B., Schlenkrich, M., Smith, J.C., Stote, R., Straub, J., Watanabe, M., Wiorkiewicz-Kuczera, J., Yin, D., Karplus, M.: All-atom empirical potential for molecular modeling and dynamics studies of proteins. J. Phys. Chem. B 102, 3586-3616 (1998)

26. Stewart, J.J.P.: Optimization of parameters for semi-empirical methods. V. Modification of NDDO approximations and application to 70 elements. J. Mol. Model. 13, 1173-1213 (2007)

27. Becke, A.D.: New mixing of Hartree-Fock and local density-functional theories. J. Chem. Phys. 98, 1372-1377 (1993)

28. Becke, A.D.: Density functional thermochemistry. III. The role of exact exchange. J. Chem. Phys. 98, 5648-5652 (1993)

29. Zhao, Y., Truhlar, D.G.: The M06 suite of density functionals for main group thermochemistry, thermochemical kinetics, noncovalent interactions, excited states, and transition elements: two new functionals and systematic testing of four M06-class functionals and 12 other functionals. Theor. Chem. Acc. 120, 215-241 (2008)

30. McClurg, R.B., Flagan, R.C., Goddard III, W.A.: The hindered rotor density-of-states interpolation function. J. Chem. Phys. 106, 6675-6680 (1997)

31. Ayala, P.Y., Schlegel, H.B.: Identification and treatment of internal rotation in normal mode vibrational analysis. J. Chem. Phys. 108, 2314-2325 (1998)

32. Furche, F., Ahlrichs, A.: Adiabatic time-dependent density functional methods for excited state properties. J. Chem. Phys. 117, 7433-7447 (2002)

33. Iikura, H., Tsuneda, T., Yanai, T., Hirao, K.: A long-range correction scheme for generalized-gradient-approximation exchange functionals. J. Chem. Phys. 115, 3540-3544 (2001)

34. Chai, J.D., Head-Gordon, M.: Systematic optimization of long-range corrected hybrid density functionals. J. Chem. Phys. 128, 084106/1084106/15 (2008)

35. Chai, J.D., Head-Gordon, M.: Long-range corrected hybrid density functionals with damped atom-atom dispersion corrections. Phys. Chem. Chem. Phys. 10, 6615-6620 (2008)

36. Frisch, M.J., Trucks, G.W., Schlegel, H.B., Scuseria, G.E., Robb, M.A., Cheeseman, J.R., Scalmani, G., Barone, V., Mennucci, B., Petersson, G.A., Nakatsuji, H., Caricato, M., Li, X., Hratchian, H.P., Izmaylov, A.F., Bloino, J., Zheng, G., Sonnenberg, J.L., Hada, M., Ehara, M., Toyota, K., Fukuda, R., Hasegawa, J., Ishida, M., Nakajima, T., Honda, Y., Kitao, O., Nakai, H., Vreven, T., Montgomery Jr., J.A., Peralta, J.E., Ogliaro, F., Bearpark, M., Heyd, J.J., Brothers, E., Kudin, K.N., Staroverov, V.N., Kobayashi, R., Normand, J., Raghavachari, K., Rendell, A., Burant, J.C., Iyengar, S.S., Tomasi, J., Cossi, M., Rega, N., Millam, J.M., Klene, M., Knox, J.E.,
Cross, J.B., Bakken, V., Adamo, C., Jaramillo, J., Gomperts, R., Stratmann, R.E., Yazyev, O., Austin, A.J., Cammi, R., Pomelli, C., Ochterski, J.W., Martin, R.L., Morokuma, K., Zakrzewski, V.G., Voth, G.A., Salvador, P., Dannenberg, J.J., Dapprich, S., Daniels, A.D., Farkas, O., Foresman, J.B., Ortiz, J.V., Cioslowski, J., Fox, D.J.: Gaussian 09, Revision A.02. Gaussian, Inc, Wallingford CT (2009)

37. Julian, R.R., Beauchamp, J.E.: Site specific sequestering and stabilization of charge in peptides by supramolecular adduct formation with 18-crown-6 ether by way of electrospray ionization. Int. J. Mass Spectrom. 210/211, 613 (2001)

38. Holm, A.I.S., Hvelplund, P., Kadhane, U., Larsen, M.K., Liu, B., Nielsen, S.B., Panja, S., Pedersen, J.M., Skrydstrup, T., Stochkel, K., Williams, E.R., Worm, E.S.: On the mechanism of electroncapture-induced dissociation of peptide dications from ${ }^{15} \mathrm{~N}$-labeling and crown-ether complexation. J. Phys. Chem. A 111, 9641-9643 (2007)

39. Jensen, C.S., Wyer, J.A., Houmoller, J., Hvelplund, P., Nielsen, S.B.: Electron-capture induced dissociation of doubly charged dipeptides: on the neutral losses and N-C $\alpha$ bond cleavages. Phys. Chem. Chem. Phys. 13, 18373-18378 (2011)

40. McClellan, J.E., Murphy III, J.P., Mulholland, J.J., Yost, R.A.: Effects of fragile ions on mass resolution and on isolation for tandem mass spectrometry in the quadrupole ion trap mass spectrometer. Anal. Chem. 74, 402$412(2002)$

41. Pham, H.T., Julian, R.R.: Mass shifting and radical delivery with crown ether attachment for separation and analysis of phosphatidylethanolamine lipids. Anal. Chem. 86, 3020-3027 (2014)

42. Ledvina, A.R., Chung, T.W., Hui, R., Coon, J.J., Tureček, F.: Cascade dissociations of peptide cation-radicals. Part 2. Infrared multiphoton dissociation and mechanistic studies of z-ions from pentapeptides. J. Am. Soc. Mass Spectrom. 23, 1351-1363 (2012)

43. Bibas, H., Koch, R., Wentrup, C.: Retro-Ene reactions in acylallene derivatives. J. Org. Chem. 63, 2619-2626 (1998)

44. Hoffmann, H.M.R.: The Ene reaction. Angew. Chem. Int. Ed. Engl. 8, 556577 (1969)

45. von Helden, G., Hsu, M.T., Gotts, N., Bowers, M.T.: Carbon cluster cations with up to 84 atoms: structures, formation mechanism, and reactivity. J. Phys. Chem. 97, 8182-8192 (1993)

46. Mesleh, M.F., Hunter, J.M., Shvartsburg, A.A., Schatz, G.C., Jarrold, M.F.: Structural information from ion mobility measurements: effects of the longrange potential. J. Phys. Chem. 100, 16082-16086 (1996)

47. Moss, C.L., Liang, W., Li, X., Turecek, F.: The early life of a peptide cation-radical. Ground and excited-state trajectories of electron-based peptide dissociations during the first 330 femtoseconds. J. Am. Soc. Mass Spectrom. 23, 446-459 (2012)

48. Hratchian, H.P., Schlegel, H.B.: Using Hessian updating to increase the efficiency of a Hessian based predictor-corrector reaction path following method. J. Chem. Theory Comput. 1, 61-69 (2005)

49. Chung, T.W., Tureček, F.: Proper and improper aminoketyl radicals in electron-based peptide dissociations. Int. J. Mass Spectrom. 301, 55-61 (2011)

50. Hao, C., Tureček, F.: Host-guest hydrogen atom transfer induced by electron capture. J. Am. Soc. Mass Spectrom. 20, 639-651 (2009)

51. Holm, A.I.S., Larsen, M.K., Panja, S., Hvelplund, P., Nielsen, S.B., Leib, R.D., Donald, W.A., Williams, E.R., Hao, C., Tureček, F.: Electron capture, femtosecond electron transfer and theory: a study of noncovalent crown ether 1, n-diammonium alkane complexes. Int. J. Mass Spectrom. 276, 116-126 (2008)

52. Chen, Y., Rodgers, M.T.: Structural and energetic effects in the molecular recognition of protonated peptidomimetic bases by 18-crown-6. J. Am. Chem. Soc. 134, 2313-2324 (2012)

53. Chen, Y., Rodgers, M.T.: Structural and energetic effects in the molecular recognition of amino acids by $18-$ Crown-6. J. Am. Chem. Soc. 134, 58635875 (2012)

54. Tureček, F., Julian, R.R.: Peptide radicals and cation-radicals in the gas phase. Chem. Rev. 113, 6691-6733 (2013)

55. Tureček, $\mathrm{F} .: \mathrm{N}-\mathrm{C}_{\alpha}$ bond dissociation energies and kinetics in amide and peptide radicals. Is the dissociation a non-ergodic process? J. Am. Chem. Soc. 125, 5954-5963 (2003)

56. Sohn, C.H., Chung, C.K., Yin, S., Ramachandran, P., Loo, J.A., Beauchamp, J.L.: Probing the mechanism of electron capture and electron transfer dissociation using tags with variable electron affinity. J. Am. Chem. Soc. 131, 5444-5459 (2009) 
57. Jones, A.W., Cooper, H.J.: Probing the mechanisms of electron capture dissociation mass spectrometry with nitrated peptides. Phys. Chem. Chem. Phys. 12, 13394-13399 (2010)

58. Jones, A.W., Mikhailov, V.A., Iniesta, J., Cooper, H.J.: Electron capture dissociation mass spectrometry of tyrosine nitrated peptides. J. Am. Soc. Mass Spectrom. 21, 268-277 (2010)

59. Zimnicka, M., Chung, T.W., Moss, C.L., Tureček, F.: Perturbing peptide cation-radical electronic states by thioxoamide groups: formation, dissociations, and energetics of thioxopeptide cation-radicals. J. Phys. Chem. A 117, 1265-1275 (2013)
60. Zimnicka, M., Moss, C.L., Chung, T.W., Hui, R., Tureček, F.: Tunable charge tags for electron-based methods of peptide sequencing. Design and applications. J. Am. Soc. Mass Spectrom. 23, 608$620(2012)$

61. Chamot-Rooke, J., Malosse, C., Frison, G., Tureček, F.: Electron capture in charge-tagged peptides. Evidence for the role of excited electronic states. J. Am. Soc. Mass Spectrom. 18, 2146-2161 (2007)

62. Hilborn, R.C.: Einstein coefficient, cross sections, f values, dipole moments, and all that. Am. J. Phys. 50, 982-986 (1982) 